\title{
Histochemical assays of secretory trichomes and the structure and content of mineral nutrients in Rubus idaeus L. leaves
}

\author{
Mirosława Chwil $^{1}$ - Mikołaj Kostryco ${ }^{1}$
}

Received: 3 April 2019 / Accepted: 18 July 2019 / Published online: 9 August 2019

(C) The Author(s) 2019

\begin{abstract}
Leaves of Rubus idaeus are a raw material, ingredients of herbal blend, and a source of antioxidants. There are no data concerning histochemistry of trichomes, and little is known about the leaf structure of this species. The aim of this study was to determine the histochemistry of active compounds and the structure of glandular trichomes, micromorphology, anatomy, and ultrastructure of leaves as well as content of elements. To determine the histochemistry of glandular trichomes, different chemical compounds were used. The leaf structure was analysed using light, scanning, and transmission electron microscopes. The content of elements was determined with atomic absorption spectrometry, and the microanalysis of the epidermis ultrastructure was carried out with a transmission electron microscope equipped with a digital X-ray analyser. In glandular trichomes, polyphenols, terpenes, lipids, proteins, and carbohydrates were identified. The main elements in the ultrastructure of the epidermis were $\mathrm{Na}, \mathrm{Mo}, \mathrm{Se}, \mathrm{Ca}$, and $\mathrm{Mg}$. In dry matter of leaves, $\mathrm{K}, \mathrm{Mg}, \mathrm{Ca}, \mathrm{P}$, and Fe were dominant. Infusions from leaves are safe for health in terms of the $\mathrm{Cd}$ and $\mathrm{Pb}$ concentrations. Leaves can be a valuable raw material. Non-glandular trichomes prevent clumping of mixed raw materials in herbal mixtures.
\end{abstract}

Keywords Red raspberry $\cdot$ Glandular trichomes $\cdot$ Cuticle $\cdot$ Stomata $\cdot$ Micromorphology $\cdot$ Anatomy $\cdot$ Ultrastructure $\cdot$ Elements

\section{Introduction}

The genus Rubus characterised by extensive morphological diversity comprises many species divided into 12 subgenera (Naruhashi et al. 2002). The complex taxonomy of this genus is based on various methods, e.g. assessment of genetic relationships between taxa with AFLP markers (Miyashita et al. 2015). Currently, the cultivation of Rubus idaeus is increasing substantially due to the nutritional value of the fruit, consumer demand, use of the raw material in various branches of industry, and production of new economically profitable varieties recommended in commodity production (Finn et al. 2005; Ali et al. 2011; Konopiński and Żuber 2013).

Handling Editor: Peter Nick

Mirosława Chwil

miroslawa.chwil@up.lublin.pl

Mikołaj Kostryco

kostryco@up.lublin.pl

1 Department of Botany and Plant Physiology, University of Life Sciences in Lublin, Akademicka 15, 20-950 Lublin, Poland
Plants from the genus Rubus, e.g. R. idaeus, R. plicatus, $R$. saxatilis, and $R$. rosifolius, and their hybrids provide various herbal raw materials (Ribeiro et al. 1986; Tomczyk and Gudej 2005). Rubi folium is an important source of a variety of health-enhancing phytocompounds (Gallaher et al. 2006; Grabek-Lejko and Wojtowicz 2014; Costea et al. 2016; Chwil and Kostryco 2018). Leaves of $R$. coreanus contain tannins (ellagic acid, sanguine H-5) and flavonoids (kaempferol, quercetin) (Om et al. 2016). The beneficial effect of $R$. idaeus and Rubus plicatus leaf extracts on the human organism is mainly exploited in medicine and food industry. $R$. idaeus leaves exhibit high antioxidant activity (Buřičová et al. 2011; Aybastier et al. 2013; Chwil and Kostryco 2018). One of the most important antioxidant enzymes contained in this raw material is catalase, which decomposes hydrogen peroxide particles, thus providing protection against negative effects of oxidative stress (Ścibior and Czeczot 2006; Romanowicz and Krzepiłko 2013).

The high efficiency of trace elements such as $\mathrm{Cu}, \mathrm{Mo}, \mathrm{Se}$, and $\mathrm{Zn}$ as cofactors of antioxidant enzymes, e.g. superoxide dismutase, glutathione peroxidase, xanthine oxidase, and sulphite oxidase, involved in scavenging of free radicals and their effects has been confirmed (Pilon et al. 2006; Mason 
2007; Ahmad et al. 2015; Wołonciej et al. 2016). In our previous studies, the highest total antioxidant activity in $R$. idaeus leaves determined with the ferric reducing antioxidant power (FRAP) and Folin-Ciocalteu methods was found for the 'Radziejowa' cultivar, while the highest radical DPPH pigmentation capacity was detected in the Laszka cultivar (Chwil and Kostryco 2018).

This indicates that $R$. idaeus leaves are a good source of exogenous antioxidants in the human diet and can be used as a main herbal raw material and a component of various herbal blends (Grabek-Lejko and Wojtowicz 2014).

As reported by Tomaszewski et al. (2014), trichomes in the leaf epidermis in plants from the genus Rubus are regarded as one of the most important traits for classification of the representatives of this genus and for determination of taxa at the level of series, sections, and even subgenera. The distribution, size, and shape of trichomes were found to vary between taxa (Upadhyaya and Furness 1998; Tomaszewski et al. 2014; Karley et al. 2015). Tomaszewski et al. (2014) distinguished three types of trichomes in Rubus plants: simple eglandular (unbranched) trichomes, eglandular branched trichomes, and very short secretory uniseriate trichomes. Costea et al. (2016) reported the presence of glandular trichomes on both surfaces of the $R$. idaeus epidermis. Despite the large variety of red raspberry cultivars and hybrids, there are insufficient literature data on the structure of the epidermis and leaf anatomy in this species. Therefore, an attempt to complete this knowledge has been undertaken. The present study is a continuation of previous investigations, in which bioactive compounds present in Rubi folium from several red raspberry cultivars were described (Chwil and Kostryco 2018).

The structure of the secretory tissue in $R$. idaeus has rarely been studied. Given the wide application of biologically active substances from Rubus plants, it is advisable to supplement the knowledge of the location and chemical composition of glandular trichomes. Therefore, an attempt to complete this knowledge has been undertaken. The aim of this study was to determine and compare the histochemistry of active compounds and the structure of glandular trichomes, micromorphology, anatomy, and ultrastructure of leaves as well as content of selected elements in the three $R$. idaeus varieties. The main research hypotheses included (1) histochemistry and (2) micromorphology of glandular trichomes as well as (3) microanalysis of elements at the level of cell ultrastructure. To our knowledge, this is the first study to provide information in the field of histochemical analyses of trichomes and microanalysis of elements at the level of cell ultrastructure in Rubus. We hope that the research results will complement knowledge in this area. The structural traits of leaves may serve as auxiliary taxonomic indications, while the biologically active metabolites may be valuable components of functional foods and may be used in phytotherapy.

\section{Material and methods}

\section{Research material}

Leaves of three Rubus idaeus L. cultivars, 'Glen Ample', 'Laszka', and 'Radziejowa', were collected from shrubs growing in a plantation located in Blinów II, south-eastern Poland (50 52' 57.03" N; $22^{\circ} 23^{\prime} 2$.663" E). Six samples of young, healthy, and well-developed leaves of each cultivar were taken from the fifth node at the onset of plant flowering. The content of micro- and macroelements as well as trace elements was determined in dry plant material. The collected leaves were dried in a natural air-drying room protected from solar radiation. Hand-made cross sections of fresh leaves were prepared for histological assays, and fragments of laminas were sampled and fixed for microscopic observations aimed at comparison of the structure of trichomes and leaf tissues.

\section{Fixation of samples and preparation of slides}

Fragments were collected from the central and apical part of fresh leaves and fixed in $4 \%$ glutaraldehyde for $6 \mathrm{~h}$ at room temperature and in $0.1 \mathrm{M}$ phosphate buffer $(\mathrm{pH} 7.0)$ at $4{ }^{\circ} \mathrm{C}$ for $48 \mathrm{~h}$. To prepare semi-thin sections, fixed samples were rinsed in phosphate buffer and dehydrated for $15 \mathrm{~min}$ in a series of ethyl alcohol at concentrations of 15, 30, 50, 70, 90, and 96 and twice in absolute ethanol. Dehydrated plant fragments were embedded in Spurr Low Viscosity resin and polymerised at a temperature of $60{ }^{\circ} \mathrm{C}$ for $48 \mathrm{~h}$. Semi-thin cross sections were made from the resin-embedded material. 1- $\mu \mathrm{m}$-thick sections were cut with a glass knife using a Reichert Ultracut $\mathrm{S}$ microtome and stained with $1 \%$ toluidine blue and $1 \%$ azure II $(1: 1)$ at $60{ }^{\circ} \mathrm{C}$ for 5 min using modified preparatory procedures (Stadtländer 2007). Stained slides were dried after rinsing with distilled water and 5\% ethyl alcohol. Periodic acid-Schiff (PAS) reactions were performed to determine the presence of polysaccharides in the cell walls (Mowry 1963).

Comparative analyses of the epidermis micromorphology and the structure of trichomes and leaf tissues of the studied cultivars were carried out using bright-field light microscopy (LM), fluorescence microscopy (FM), and electron scanning (SEM) microscopy.

\section{Microscopy}

Fluorescence microscope Hand-made cross sections were prepared from fresh leaf material in order to determine groups of compounds contained in the glandular trichomes and analyse the cuticle layer on the surface of the glandular trichomes and epidermis cells. The sections were placed in a drop of a fluorochrome $(0.01 \%$ auramine $\mathrm{O})$ and embedded in a $50 \%$ glycerol solution (Heslop-Harrison and Shivanna 1977). 
Observations were carried out in a Nikon Eclipse 90i fluorescence microscope equipped with an FITC filter (excitation light 465-495 $\mathrm{nm}$ ) and a barrier filter (wavelength 515$555 \mathrm{~nm})$.

Bright-field light microscope Comparative analyses of epidermis cells and assimilation mesophyll in the leaves of the three Rubus idaeus cultivars were carried out on hand-cut and semithin preparations. Microscopic observations and photographic documentation were made under a Nikon Eclipse 400 brightfield light microscope.

Scanning electron microscope After dehydration in an acetone series at concentrations of 15, 30, 50, 70, 90, and 99.5\% (anhydrous acetone was used twice), fixed plant samples were critical-point-dried in liquid $\mathrm{CO}_{2}$ in an EmiTech K850 dryer. Next, the samples were coated with gold using an EmiTech K550X sputter coater. Observations of the leaf epidermis surface and photographic documentation were made using a Tescan VEGA II LMU scanning electron microscope.

Transmission electron microscopy Fixed leaf fragments were contrasted in a $1.5 \%$ osmium tetraoxide solution in order to prepare semi-thin and ultrathin sections. After rinsing with distilled water, $0.5 \%$ aqueous uranyl acetate was applied for $2 \mathrm{~h}$ at room temperature. When double rinsed with distilled water, fragments of nectaries were dehydrated for $15 \mathrm{~min}$ in a series of the following concentrations of ethyl alcohol: 15, 30, 50, 70, 90, 96, and 99.8\%, and twice in absolute ethanol. The dehydrated samples were embedded in Spurr Low Viscosity resin and polymerised at a temperature of $60{ }^{\circ} \mathrm{C}$ for $48 \mathrm{~h}$. Ultrathin 70-nm-thick sections were cut with a glass knife using a Reichert Ultracut S microtome. Next, they were stained for 40 min with an $8 \%$ solution of uranyl acetate in $0.5 \%$ acetic acid using modified preparatory procedures (Stadtländer 2007). When double rinsed with distilled water (10 $\mathrm{min}$ ), the Reynolds reagent was applied for $15 \mathrm{~min}$ (Reynolds 1963). After rinsing with water, the sections were dried. The ultrastructure of the nectary cells was viewed under a high-resolution transmission electron microscope (TEM, FEI, USA; Tecnai Spirit $\mathrm{G}^{2}$ ).

\section{Histochemistry}

The main groups of bioactive compounds present in the glandular trichomes in the epidermis of fresh Rubus idaeus 'Laszka' and 'Radziejowa' leaves were stained with relevant histochemical assays using the following chemical compounds: Nadi reagent (naphthol and dimethyl-paraphenylene diamine) for terpenoids and essential oils (David and Carde 1964), Sudan Red 7B (Brundrett et al. 1991) and Sudan Black B (Lison 1960) for total lipids, Nile blue A (Jensen 1962) for neutral and acidic lipids, Lugol's solution for proteins (Jensen
1962), Fehling's reagent (Ayoola et al. 2008) for total sugars, PAS reagent (Feder and O'brien 1968) for polysaccharides, and iron chloride (Johansen 1940) and potassium dichromate (Gabe 1968) for phenolic compounds.

\section{Microanalysis of elements in selected parts of epidermis cells}

The qualitative and quantitative microanalysis of the content of selected elements N, P, K, Na, Ca, Mg, S, B, Fe, Zn, Se, $\mathrm{Mo}, \mathrm{Cd}$, and $\mathrm{Pb}$ in the cuticle and other parts of the cell wall as well as the cytoplasm and vacuoles of the leaf epidermis in Rubus idaeus 'Glen Ample', 'Laszka', and 'Radziejowa' was performed with the use of ultrathin non-contrasted sections (thickness $100 \mathrm{~nm}$ ). The microanalysis was carried out with a high-resolution transmission electron microscope JEM 1400 (JEOL Co., Japan 2008) and a digital microscope controlled from the Windows XP platform and equipped with an X-ray microanalyser (EDS INCA Energy TEM, Oxford Instruments, UK) and an 11-megapixel TEM Morada G2 camera (EMSIS GmbH, Germany).

\section{Determination of elements}

Six samples of young, healthy, and well-developed leaves of each cultivar were taken from the fifth node at the onset of plant flowering. Immediately after sampling, the leaves were dried in a natural air-drying room protected from solar radiation. The dried samples were ground in an analytical mill. 0.5$\mathrm{g}$ aliquots of milled plant samples were transferred to Teflon tubes, and $10 \mathrm{~cm}^{3}$ of $\mathrm{HNO}_{3}$ was added. Next, the plant material was mineralised in a CEM Mars Xpress microwave oven at a temperature of $210{ }^{\circ} \mathrm{C}$ and under pressure of $7 \mathrm{~atm}$. The mineralizates were quantitatively transferred into $50-\mathrm{cm}^{3}$ volumetric flasks and diluted with demineralised water (conductivity of $0.055 \mu \mathrm{S} / \mathrm{cm}$ ) to the indicated volume.

The solutions were analysed using a Varian SpectrAA 20FS flame atomic absorption spectrophotometer with the following settings (absorption, slit width, lamp current) for the selected elements, respectively: $\mathrm{Ca}(422.7 \mathrm{~nm}, 0.5 \mathrm{~nm}, 10 \mathrm{~mA}), \mathrm{Mg}$ (202.6 nm, $1 \mathrm{~nm}, 4 \mathrm{~mA}), \mathrm{Fe}(248.3 \mathrm{~nm}, 0.2 \mathrm{~nm}, 5 \mathrm{~mA}), \mathrm{Cu}$ (324.8 nm, $0.5 \mathrm{~nm}, 4 \mathrm{~mA})$, and $\mathrm{Zn}(213.9 \mathrm{~nm}, 1 \mathrm{~nm}, 5 \mathrm{~mA})$. In turn, the emission and slit width was $589 \mathrm{~nm}$ and $0.2 \mathrm{~nm}$ for $\mathrm{Na}$ and $589 \mathrm{~nm}$ and $0.2 \mathrm{~nm}$ for K, respectively; the HCL lamp was not used for both these elements. A 100-mm slit burner based on a stoichiometric acetylene/air mixture was used as an atomiser. To avoid ionization of $\mathrm{Ca}-, \mathrm{Mg}_{-}, \mathrm{Na}$-, and $\mathrm{K}$-containing samples and to ensure appropriate atomisation conditions, Schinkel spectral buffer $\left(10 \mathrm{~g} / \mathrm{dm}^{3} \mathrm{CsAl}+100 \mathrm{~g} / \mathrm{dm}^{3} \mathrm{La}\right)$ was used at a level of $10 \%$ of the sample dose.

To determine $\mathrm{Pb}$ and $\mathrm{Cd}$, the solutions were analysed using an inductively coupled plasma mass spectrophotometer (ICP Mass Spectrometer Varian MS-820). Argon with a purity of 
Fig. 1 Fragments of the adaxial epidermis surface in the leaves of R. idaeus 'Glen Ample'. a Nonglandular trichomes on the epidermis surface and $\mathbf{b}$ surface of the midrib are visible unicellular non-glandular trichomes varied in length: short (arrowhead) and long (double arrowhead). c, $\mathbf{d}$ Smooth cuticle on the epidermis surface
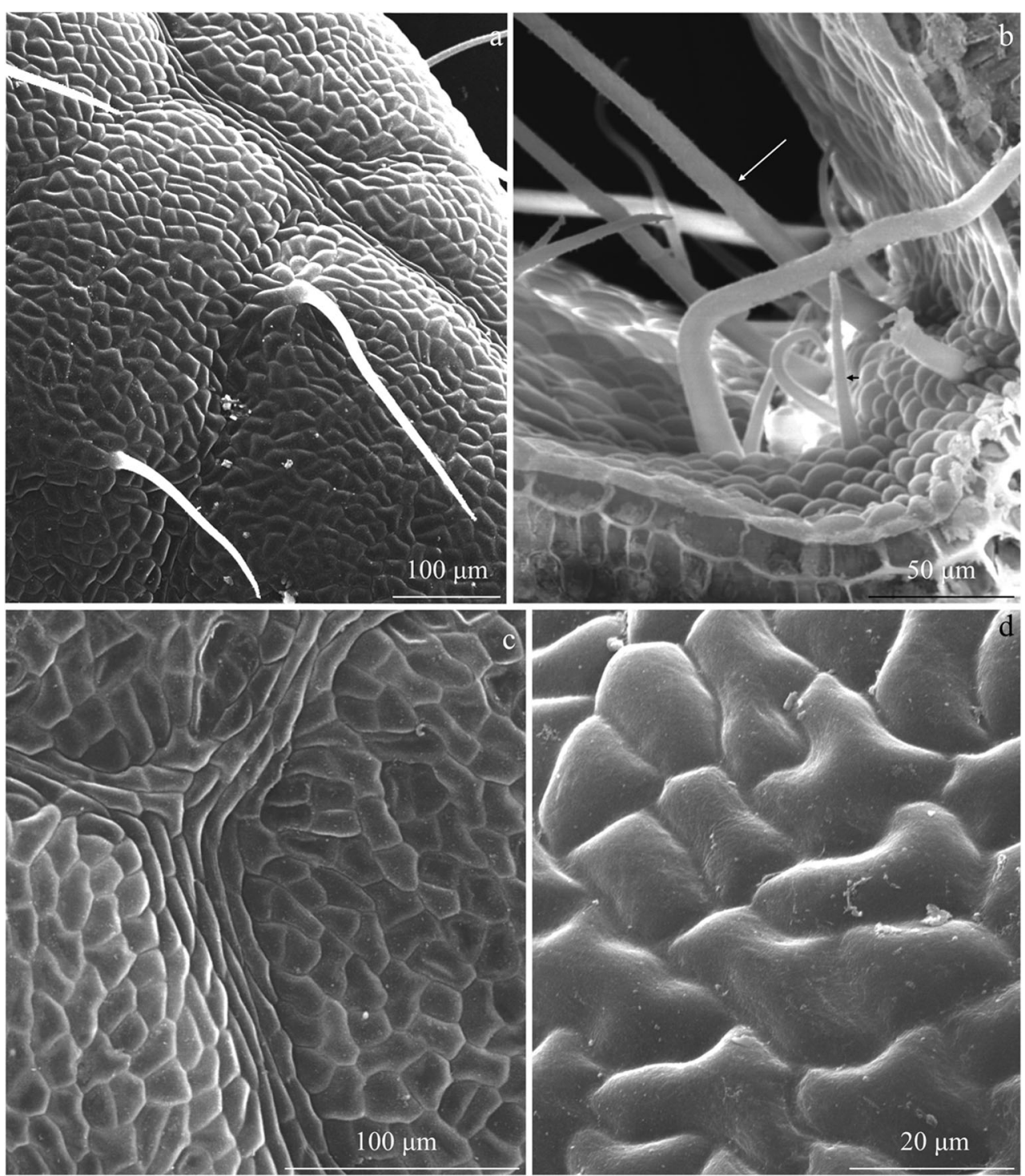

99.999\% was the plasma-forming gas. No reaction chamber (CRI) was used in the analysis. The following parameters were adopted: plasma flow-16 $\mathrm{dm}^{3} / \mathrm{min}$, nebuliser flow$0.98 \mathrm{dm}^{3} / \mathrm{min}$, RF power- $1.38 \mathrm{~kW}$, and sampling depth$6.5 \mathrm{~mm}$, and ${ }^{114} \mathrm{Cd},{ }^{206} \mathrm{~Pb},{ }^{207} \mathrm{~Pb}$, and ${ }^{208} \mathrm{~Pb}$ isotopes were used.

The determination was carried out with the standard curve method with deuterium lamp background correction. Ultra Scientific standards with a purity of $99.999 \%$ were used for the analysis.

The content of total phosphorus in air-dried leaves of the three $R$. idaeus cultivars was determined with the spectrophotometric method in accordance with the PN-ISO 6491:2000 standard. Samples of ground plant material (2.5 g) were mixed with $1 \mathrm{~g}$ of calcium carbonate and incinerated in an electric muffle furnace at $550^{\circ} \mathrm{C}$. The ash was transferred to a $250-\mathrm{ml}$ beaker with 20-50 $\mathrm{ml}$ of water. Hydrochloric acid was added until effervescence ceased and additional $10 \mathrm{ml}$ of hydrochloric acid was added. The beaker was placed in a sand bath and evaporated to dryness to obtain an insoluble silica form. After cooling and addition of $10 \mathrm{ml}$ of nitric acid (V), the residue was boiled for $5 \mathrm{~min}$ in the sand bath. The liquid was transferred to a 500-ml volumetric flask and filtered. A filtrate aliquot was diluted with water to obtain a solution with a concentration not exceeding $40 \mu \mathrm{g} / \mathrm{ml}$. Ten millilitres of the solution was transferred to a test tube with the addition of $10 \mathrm{ml}$ of vanadate-molybdate reagent. A portion of the solution was transferred to a measuring cuvette, and absorbance was measured spectrophotometrically at a wavelength of $430 \mathrm{~nm}$ against a reference solution. A calibration curve was made by plotting absorbance against the corresponding concentrations of standard phosphorus solutions.

\section{Morphometric analyses}

The length and width as well as the surface area of the secretory head and stalk of glandular trichomes were measured in 
Fig. 2 Fragments of the adaxial epidermis surface in the leaves of R. idaeus 'Laszka'. a, b Nonglandular trichomes: short (arrowhead), medium length (arrow), and long (double arrowhead) - numerous glandular trichomes on the surface of the midrib (double arrows) (a) and less dense trichomes on other branching veins (b). c Glandular trichomes with a multicellular head (double arrows) are visible non-glandular trichomes on the surface of the midrib: short (arrowhead), medium length (arrow), and long (double arrowhead). d Glandular trichome with a multicellular, two-layered stalk (in the outline) and a spherical head (double arrows) and smooth cuticle on the epidermis surface
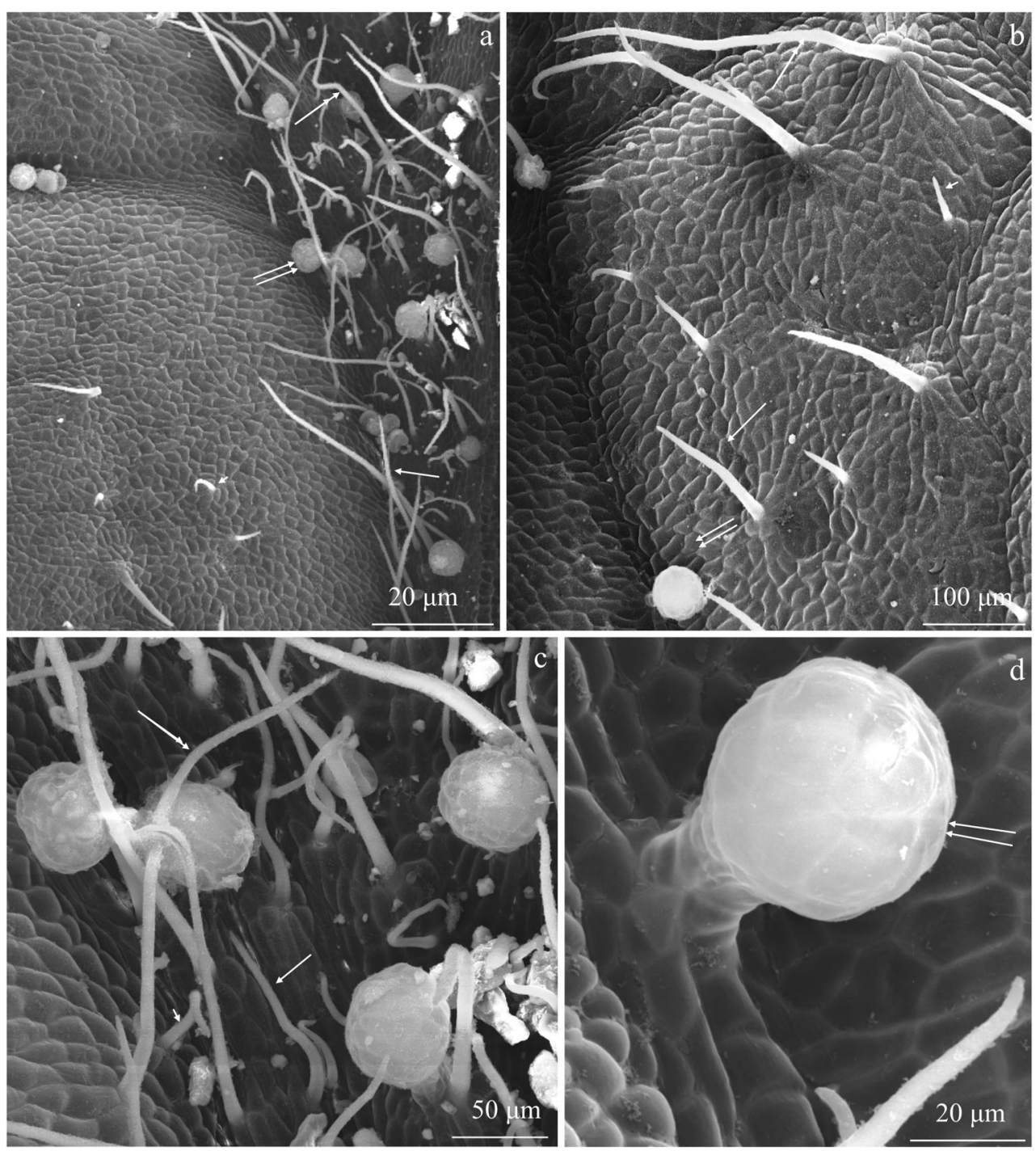

the adaxial epidermis of the leaves from the three cultivars. In the abaxial epidermis, the size of stomata, i.e. their length and width, as well as the thickness of the cuticular ledge and the length of the groove between the cuticular ledges was compared. The height and width of epidermal cells as well as the size of palisade parenchyma cells in the subcuticular layer were measured on both surfaces of the leaf epidermis in the examined cultivars. The thickness of the lamina and the palisade and spongy parenchyma was compared. The morphometric measurements of the epidermis and tissue structures were performed using LM (Nikon Eclipse 90i) equipped with a computer program for microscopic image analysis (Nikon NIS-Elements version 3.0, Advance Research).

\section{Statistical analysis of the research results}

Morphometric measurements of the trichomes and leaf tissues were carried out in 20 replicates, and the content of the selected elements was determined in four replicates in the three cultivars. The mean values of the measurements and determinations and the standard deviation (stdev. $p$; division by $n$ ) were calculated with the Microsoft Excel 2013 program. The significance of differences between the cells of the analysed tissues was analysed statistically with the use of Statistica 6.0 software. The differences between the traits were evaluated with one-way analysis of variance (ANOVA). Statistical inference was carried out at the significance level of $p<0.05$.

\section{Results}

\section{Morphology of the epidermis}

Non-glandular trichomes There were sparse non-glandular trichomes in the adaxial epidermis of the leaves of the three analysed $R$. idaeus cultivars. The trichomes were unicellular, straight, bristly, and sharply pointed. In terms of the length, 
Fig. 3 Fragments of the adaxial epidermis surface in the leaves of $R$. idaeus 'Radziejowa'. a, b Nonglandular and glandular trichomes (double arrows) growing on the surface of the midrib. $\mathbf{c}$ Unicellular non-glandular trichome and smooth cuticle with a wax coating. $\mathbf{d}$ Glandular trichome with a multicellular, two-layered stalk (in the outline) and a multicellular head
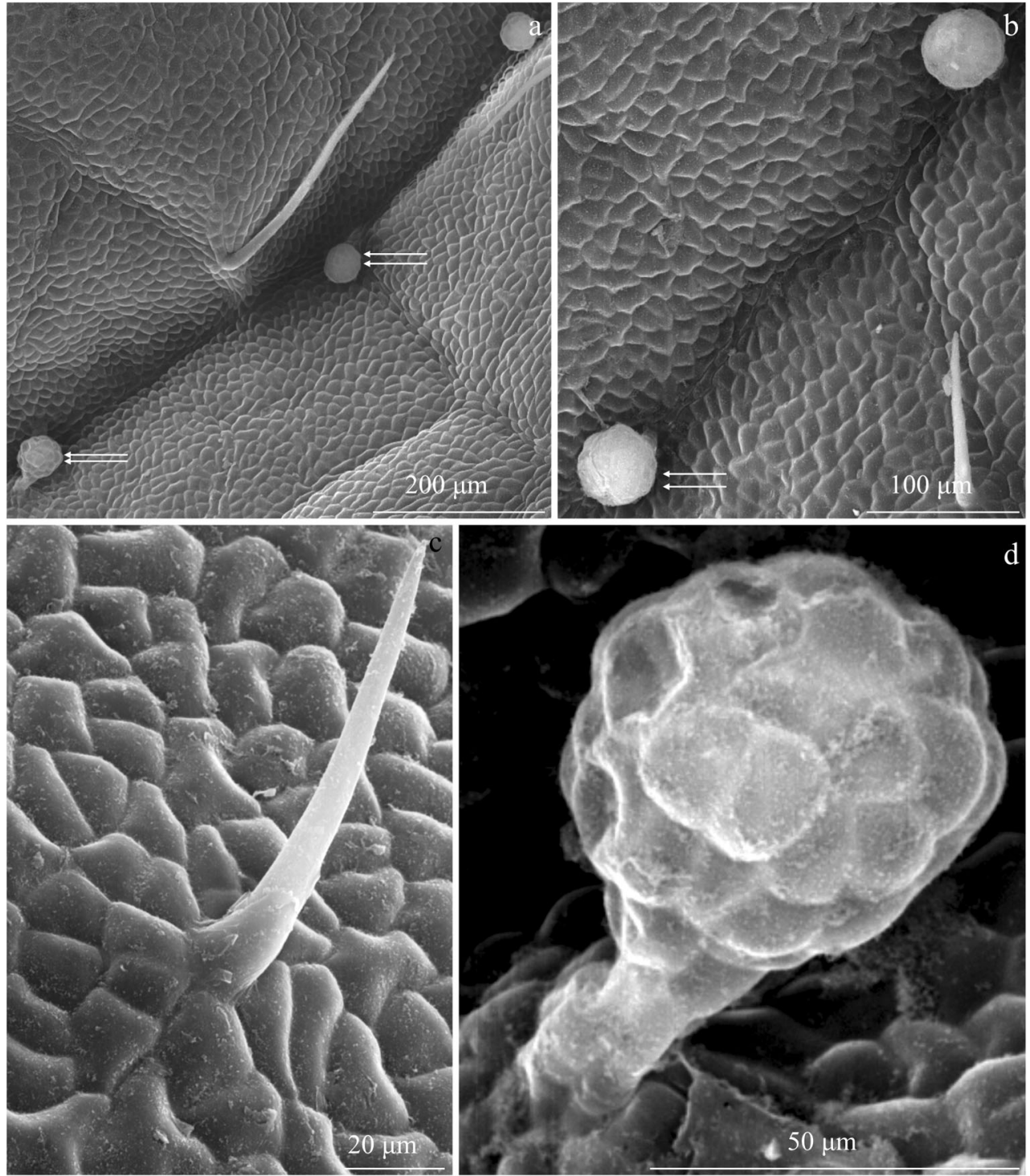

short, medium-length, and long trichomes were distinguished (Figs. 1a, b, 2a, b, and 3a-c).

The trichomes were also present on the surface of the midrib in the abaxial epidermis of the analysed cultivars. In other fragments of the abaxial epidermis, they were denser than those on the midrib surface. The surface of epidermis cells was visible between them (Figs. $4 b, 5 b$, c, and $6 c$ ).

The non-glandular trichomes in the intercostal fields in the adaxial leaf epidermis were very long, twisted, and unicellular with a sharply pointed tip. They were distributed densely, masking the epidermis surface (Figs. 4a, b, 5a, c, and 6a, b).

Glandular trichomes Secretory glandular trichomes were observed in the adaxial epidermis of the 'Laszka' and 'Radziejowa' leaves. No such structures were found in 'Glen Ample'. The glandular trichomes were located on the surface of the midrib epidermis. They were especially abundant on the midrib in the 'Laszka' cultivar (Figs. 3a and 7a) and less dense in 'Radziejowa' (Fig. 5a). Glandular trichomes were also observed on successive branches of vascular bundles (Figs. 2b, c and $3 a, b)$.

The glandular trichomes had a multicellular elliptical or spherical head (20-26 cells in the outline) (Fig. 7b-f). Due to exosecretion, the secretion accumulated in the subcuticular space formed a conical protuberance of the cuticle rupturing at the apex (Fig. $7 \mathrm{~g}, \mathrm{~h}$ ) or a typical spherical bulge (Fig. 7i) at the apex of the trichome head. The height of the secretory head was $42 \mu \mathrm{m}$ and $53 \mu \mathrm{m}$ in 'Radziejowa' and 'Laszka', respectively. Its width was similar, i.e. in the range of $43-45 \mu \mathrm{m}$, in both cultivars. The head was located on a multicelled, multiple-layered (2 layers in the outline) stalk. There were 3-7 stalk cells in one layer. The stalk in 'Radziejowa' was by $30 \%$ longer than the stalk in the 'Laszka' epidermis $(19 \mu \mathrm{m})$. The height of the glandular trichomes in both cultivars was similar $(69-71 \mu \mathrm{m})$. Their surface in the outline was in the range of 1419-1867 $\mu \mathrm{m}^{2}$ (Table 1). 
Fig. 4 Fragments of the abaxial epidermis surface in the leaves of R. idaeus 'Glen Ample'. a Sparse non-glandular trichomes on the surface of the midrib, short (arrowhead), medium length (arrow), and long (double arrowhead), are visible striated cuticle on the surface of epidermis cells. b, c Densely growing long and twisted non-glandular trichomes and stomata (double arrows) (c). d Stomata, striated or smooth cuticle on the surface of epidermis cells, and thick cuticular ledges

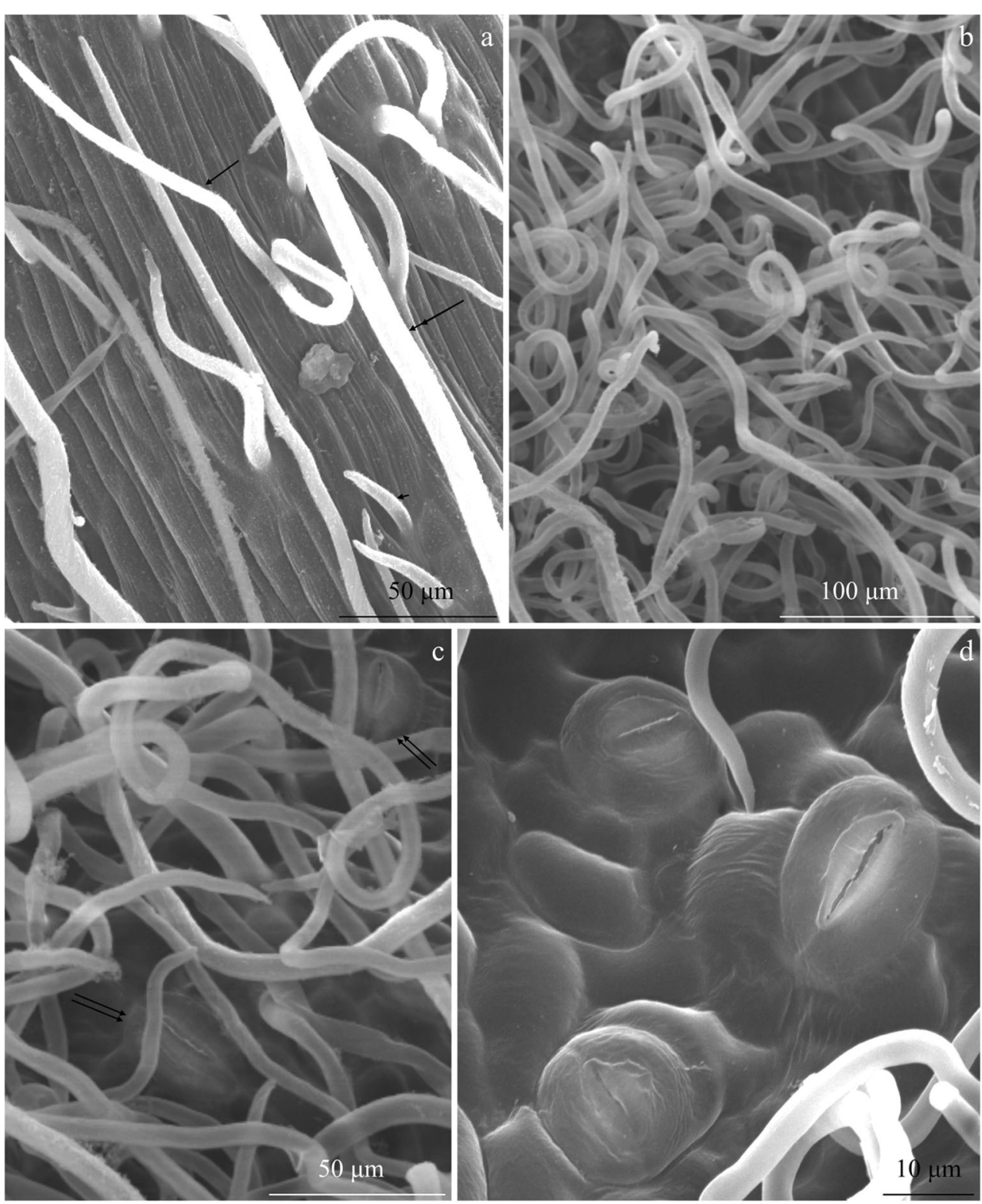

Histochemistry of glandular trichomes For the first time, histochemical assays were employed to stain the selected groups of bioactive compounds in the glandular trichomes of $R$. idaeus 'Laszka' and 'Radziejowa'. Various groups of active compounds were detected. In the reaction with the Nadi reagent, terpene compounds present in the glandular trichomes were stained purple (Fig. 8a). The reaction with Sudan Red 7B and Sudan Black B resulted in red (Fig. 8b) and dark blue (Fig. $8 \mathrm{c}$, d) staining of lipid compounds, respectively. Nile blue stained acid lipids blue (Fig. 8e, f). After application of Lugol's solution, pectin compounds exhibited a positive (yellow) staining reaction (Fig. 8g, h). Fehling's reagent stained carbohydrates brown-red, whereas PAS reaction stained polysaccharides pink (Fig. 8j). The addition of potassium dichromate or iron chloride yielded brown (Fig. 8k) or black (Fig. 81) staining of polyphenolic compounds, respectively (Table 2 ).
Cuticle The outer wall of the adaxial epidermis cells in the analysed $R$. idaeus cultivars was tetra-, penta-, or hexagonal in the outline. The cuticle on its surface was smooth and had a fine wax coating (Figs. 1a, c, d, 2a-d, and 5a-d). In turn, the cuticle was striated on the stomata and on the midrib in the abaxial epidermis and smooth or delicately striated on the other epidermis cells (Figs. 4a, d, 5c, d, and 6c, d).

Stomata The $R$. idaeus leaves are classified as the hypostomatic type. The stomata were located at the level or above the level of the other epidermis cells (Figs. 4d, 5d, and $6 \mathrm{~d})$. The length and width of the stomata in the examined cultivars were in the range of $10-22 \mu \mathrm{m}$ and $8-19 \mu \mathrm{m}$, respectively. The largest and the smallest stomata were found in the epidermis of 'Radziejowa' and 'Laszka', respectively. The stomata were characterised by thick cuticular ledges (1.9- 
Fig. 5 Fragments of the abaxial epidermis surface in the leaves of R. idaeus 'Laszka'. a, b Trichomes on the surface of the midrib are visible sparse nonglandular trichomes: short (arrowhead), medium length (arrow), and long (double arrowhead) and striated cuticle on the surface of epidermis cells (b). c Long, twisted non-glandular trichomes masking the epidermis surface. d Long, bent nonglandular trichomes and stomata (double arrows) located at the level or above epidermis cells
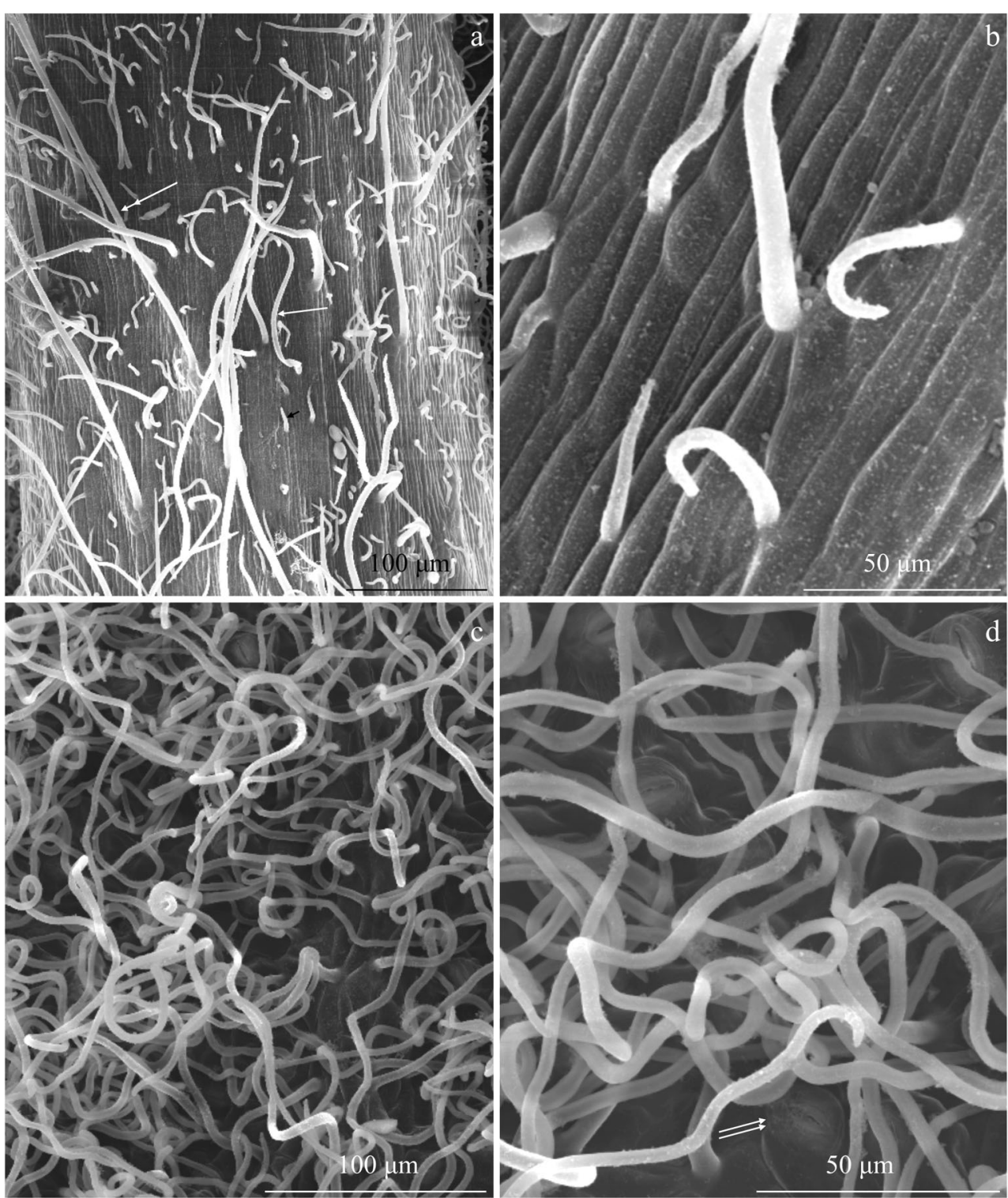

$3 \mu \mathrm{m})$. The length of the groove between the ledges ranged from 5 ('Laszka') to 12 ('Radziejowa') $\mu \mathrm{m}$ (Table 3).

\section{Anatomy}

The largest and the smallest cells of the adaxial leaf epi-

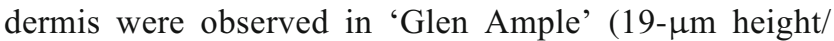
$24-\mu \mathrm{m}$ length) and 'Radziejowa' $(17 / 17 \mu \mathrm{m})$, respectively. An inverse relationship in terms of this trait was found between these cultivars in the abaxial epidermis. The analysed leaves represent the bifacial type (Fig. 9a, b, d-f). The palisade parenchyma cells formed two layers. The largest palisade cells in the subepidermal layer were noted in 'Glen Ample' (35- $\mu \mathrm{m}$ height/7- $\mu \mathrm{m}$ width). The values of these parameters in the other two cultivars, i.e. 'Laszka' and 'Radziejowa', were in the range of 25$29 \mu \mathrm{m}$ and $8-9 \mu \mathrm{m}$, respectively. The thickness of the palisade parenchyma and the lamina in 'Glen Ample' and 'Radziejowa' was similar, i.e. in the range of 51$52 \mu \mathrm{m}$ and 121-125 $\mu \mathrm{m}$, respectively. The thinnest lamina and palisade parenchyma layer were observed in 'Laszka'. The palisade parenchyma layer in the examined cultivars accounted for approximately $41 \%$ of the lamina thickness. The ratio of the palisade to sponge parenchyma in the studied cultivars ranged from 1.1 ('Laszka') to 1.3 ('Glen Ample') (Table 4). Near the large vascular bands, especially in the main vein, calcium oxalate crystals were visible (Fig. 9c).

\section{Ultrastructure of epidermal and assimilation cells}

The epidermis cells in $R$. idaeus leaves produced a thick periclinal outer cell wall (Fig. 10a). On the surface of the epidermis, there was a cuticle strand (Fig. 10b-d). The 
Fig. 6 Fragments of the abaxial epidermis surface in the $R$. idaeus 'Radziejowa' leaves. a, b Dense, twisted non-glandular trichomes. c Surface of the midrib. d Stomata (double arrows), striated cuticle on the surface of stomatal cells, and a smooth or striated cuticle on the surface of other epidermis cells

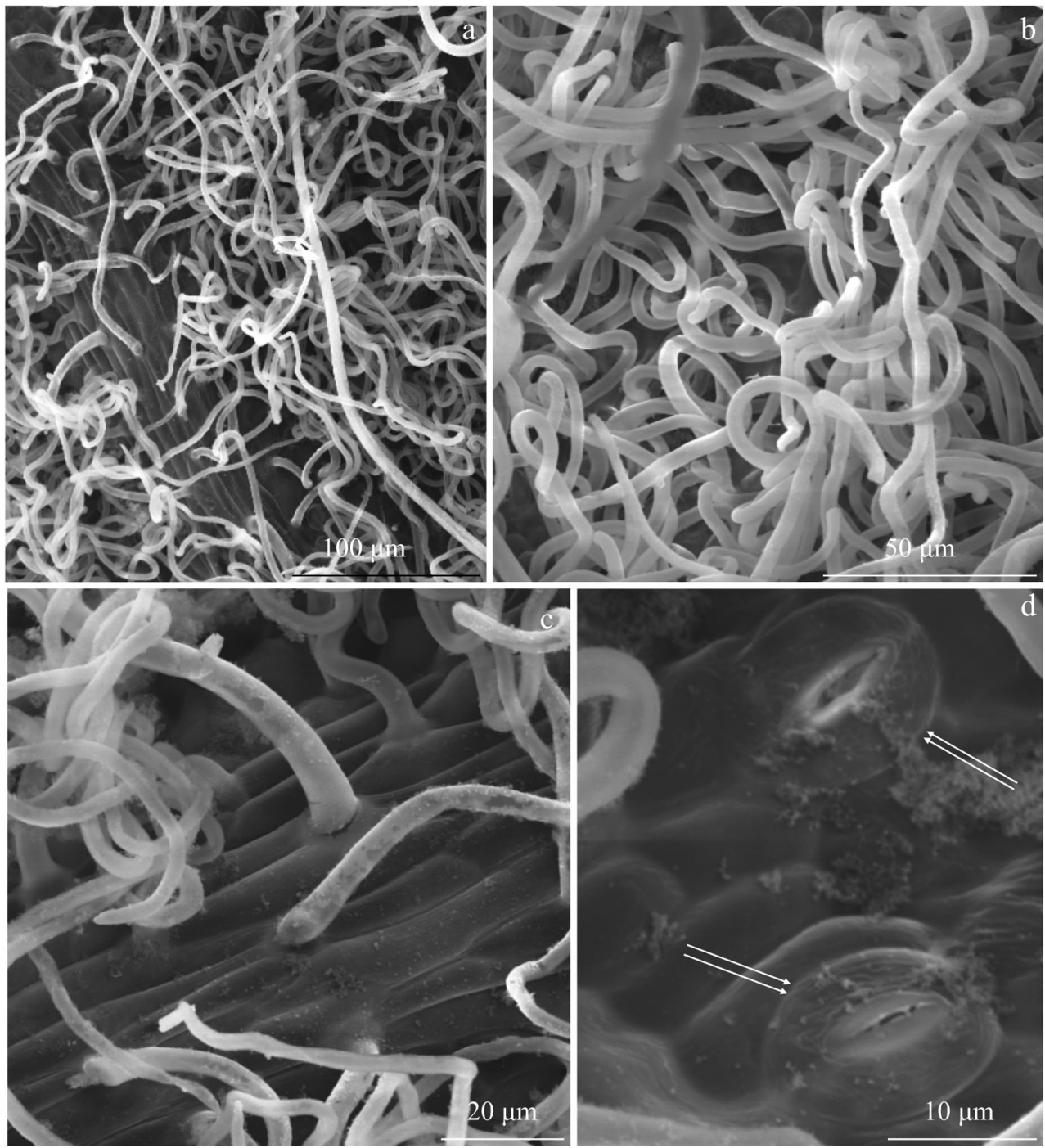

protoplast of these cells contained a parietal cytoplasm and single mitochondria with a well-developed membrane system (Fig. 10e). The palisade mesophyll cells had a large nucleus with a thick nucleoplasm and a dark nucleolus, varied degrees of vacuolization (Fig. 10a), numerous plastids with a distinct thylakoid system (Figs. 4b and 11a), mitochondria (Fig. 11a, c), and Golgi apparatus composed of 4-6 cisternae and a number of dictiosomal vesicles (Fig. $11 \mathrm{~d}, \mathrm{e})$.

\section{Microanalysis of elements in selected parts of epidermis cells}

The microanalysis of the selected elements at the level of the ultrastructure of epidermis cells (cuticle, the rest of the cell wall, cytoplasm, and vacuoles) revealed their highest concentrations in 'Laszka'. The cuticle layer was predominated by $\mathrm{Na}, \mathrm{Se}$, and Mo. In turn, the other part of the cell wall exhibited the highest concentrations of $\mathrm{Ca}, \mathrm{Na}$, and Mo in 'Glen Ample' and 'Radziejowa'. In turn, there was a substantial concentration of $\mathrm{Ca}, \mathrm{Mg}$, and $\mathrm{Mo}$ in the cytoplasm of 'Laszka . Ca, Mo, Na, and Se dominated in 'Laszka' and 'Radziejowa' (Figs. 12 and 13).

\section{Content of elements in leaf dry mass}

The concentration of the $\mathrm{K}, \mathrm{Ca}, \mathrm{Mg}, \mathrm{P}$, and Fe elements in the analysed $R$. idaeus leaves differed between the cultivars. The elements were aligned according to the growing content as follows: $\mathrm{K}>\mathrm{Ca}>\mathrm{Mg}>\mathrm{P}>\mathrm{Fe}$ ('Glen Ample'), $\mathrm{K}>\mathrm{Ca}>\mathrm{P}>\mathrm{Mg}>\mathrm{Fe}$ ('Laszka'), and $\mathrm{K}>\mathrm{Mg}>\mathrm{Ca}>\mathrm{P}>$ $\mathrm{Fe}$ ('Radziejowa'). The amount of sodium in the three examined cultivars was below the limit of determination. In turn, the content of zinc was similar in the leaves of 'Laszka' and 'Radziejowa' ( $40 \mathrm{mg} / \mathrm{kg}$ d.w.), and by ca. $14 \%$ lower in 'Glen Ample' than in the other two cultivars. The highest concentration of copper was found in 'Laszka' (34.1 $\mathrm{mg} / \mathrm{kg}$ d.w.), while the other two cultivars were 

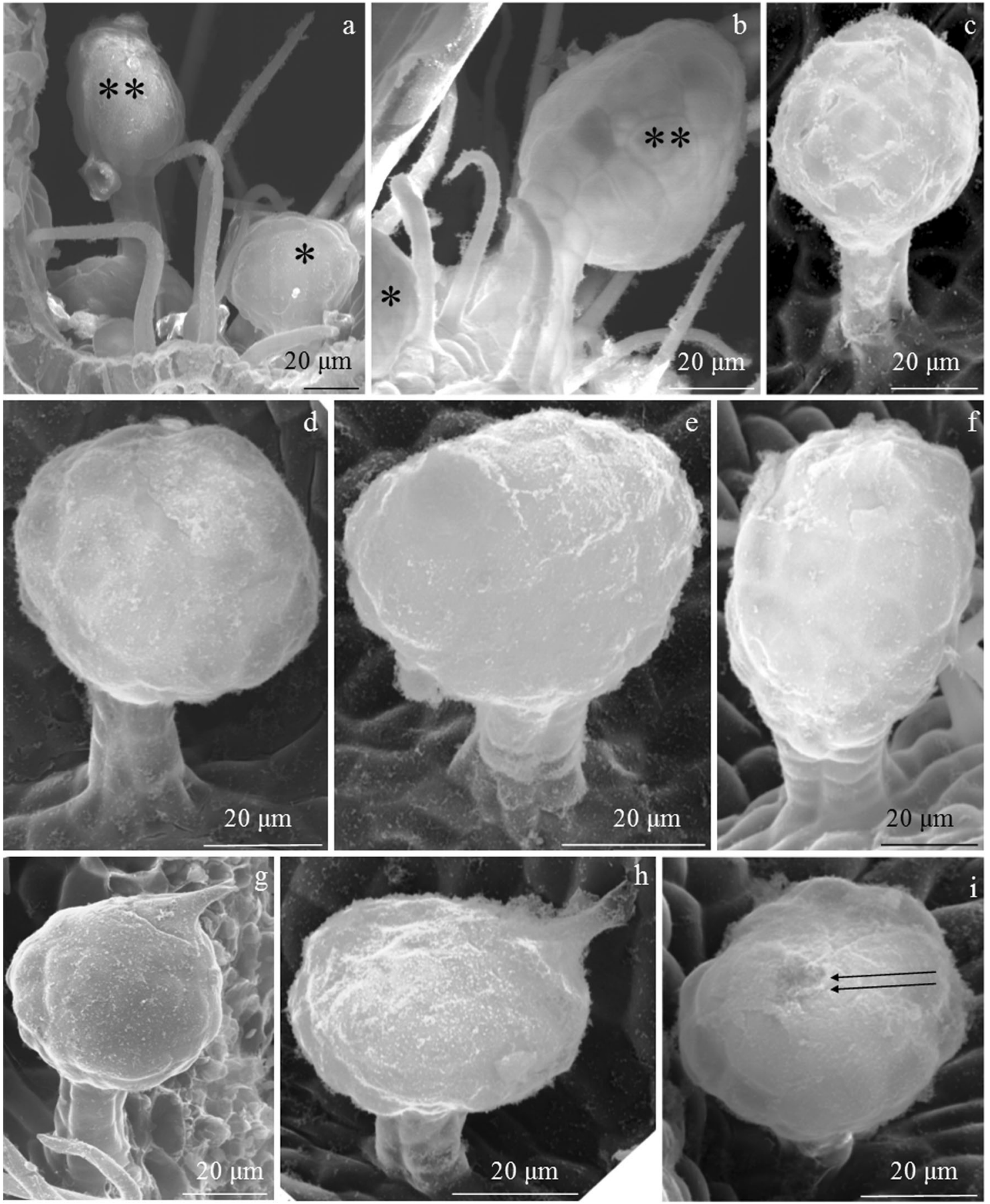

Fig. 7 Glandular trichomes in the epidermis of R. idaeus 'Laszka' and 'Radziejowa' leaves. a, b Visible spherical (asterisk) and elliptical (double asterisk) head of glandular trichomes in the epidermis of the midrib. c Glandular trichome with a short stalk and a multicellular

head. d-f Visible two-layered stalk and a spherical (d, e) and elliptical (f) multicellular head of glandular trichomes. g, h Conical cuticle ruptured at the apex by accumulating secretion. i Spherical secretory head with an apical cuticle thickness (double arrows)

characterised by a ca. $68 \%$ lower concentration of this element. The zinc content in the leaves of the three cultivars was similar and ranged from 34 to $40 \mathrm{mg} / \mathrm{kg}$ d.w. Trace elements, i.e. cadmium and lead, were present at very low concentrations (well below the permissible levels) in the leaves of the analysed cultivars (Table 5).

\section{Discussion}

\section{Micromorphology}

The hypostomatic type of leaf lamina of the $R$. idaeus cultivars analysed in this study is present in Prunus laurocerasus 
Table 1 Size of glandular trichomes in the adaxial epidermis in two R. idaeus cultivars

\begin{tabular}{|c|c|c|c|c|}
\hline \multirow[t]{2}{*}{ Trait } & & & \multicolumn{2}{|l|}{ Cultivar } \\
\hline & & & $\begin{array}{l}\text { 'Laszka' } \\
\text { Mean } \pm \text { SD }\end{array}$ & 'Radziejowa' \\
\hline Height & Secretory head & $\mu \mathrm{m}$ & $42.4 \pm 5.4^{\mathrm{b}}$ & $52.6 \pm 3.0^{\mathrm{a}}$ \\
\hline Width & & & $44.5 \pm 6.7^{\mathrm{a}}$ & $43.0 \pm 8.1^{\mathrm{a}}$ \\
\hline Surface area & & $\mu \mathrm{m}^{2}$ & $1418.9 \pm 182.4^{\mathrm{b}}$ & $1867.1 \pm 269.7^{\mathrm{a}}$ \\
\hline Length & Stalk & $\mu \mathrm{m}$ & $27.0 \pm 3.7^{\mathrm{a}}$ & $18.8 \pm 2.6^{\mathrm{b}}$ \\
\hline Width & & & $15.0 \pm 2.7^{\mathrm{a}}$ & $14.5 \pm 1.9^{\mathrm{a}}$ \\
\hline Surface area & & $\mu \mathrm{m}^{2}$ & $383.9 \pm 55.9^{\mathrm{a}}$ & $270.0 \pm 9.1^{\mathrm{b}}$ \\
\hline
\end{tabular}

Means followed by the same letter are not significantly different between cultivars $(p \leq 0.05)$

(Schreiber et al. 1995) as well as plants from the genera Sorbus and Sorbaria (Krivoruchko and Gamulya 2013; Song and Hong 2014). As shown by our investigations and literature data, the abaxial epidermis in R. idaeus had twisted unicellular non-glandular trichomes (Fell and Rowson 1960; Tomaszewski et al. 2014; Karley et al. 2015). Their length in the epidermis of $R$. loganobaccus leaves ranged from 0.3 to $0.7 \mathrm{~mm}$ (Fell and Rowson 1960). The non-glandular trichomes in the three cultivars analysed in the present study can be classified according to Tomaszewski et al. (2014) as the simple unbranched type and three different subtypes (short, medium-length, and long). According to the classification of trichomes proposed by Payne (1978), acerate, aduncate, angler, arrect, and attenuate protective trichomes were distinguished in the epidermis of $R$. idaeus leaves.

The non-glandular trichomes in the intercostal fields in the abaxial epidermis were densely distributed, masking the epidermis surface in the three $R$. idaeus cultivars. As reported by Upadhyaya and Furness (1998), there were 7-82 trichomes per $1 \mathrm{~mm}^{2}$ of the epidermis in several $R$. idaeus cultivars. According to the division proposed by Tomaszewski et al. (2014), based on the density of non-glandular trichomes, the non-glandular trichomes in the adaxial epidermis described in the present study can be classified into the first group $(<10 \%)$, while those present in the abaxial epidermis represent the third or fourth group (>90\%).

The size and topography of trichomes are modified by environmental conditions (Upadhyaya and Furness 1998; Wilkens et al. 1996). Non-glandular trichomes in the epidermis serve various functions. They constitute a protective barrier against pests, e.g. from the genera Amphorophora and Tetranychus (Levin 1973). The presence of trichomes on the epidermis surface was found to reduce the number of pests feeding on $R$. idaeus leaves (Karley et al. 2015). Nonglandular trichomes are involved in adaptation to adverse environmental conditions. They produce hydrophilic substances that help to retain water, thereby preventing drying out and promoting the growth of young organs. This hyaline material contained mainly carbohydrates derived from the partial degradation of the trichome cell wall (Lusa et al. 2015). The secretion of colleters on the surface of buds and floral elements protects against water loss as well (Mayer et al. 2013). Some glandular trichomes provide food for pollinators (Pansarin and Maciel 2017), while others secrete terpenoids, phenolic compounds, and insect-repellent proteins (Lusa et al. 2015). Accumulation of e.g. terpenoids in trichomes suggests a chemo-ecological function in the interaction of plants with insects or herbivores (Amrehn et al. 2014).

A similar structure of glandular trichomes to that shown in this study, i.e. the presence of a multicellular or spherical head located on a multicelled multiple-layered (2 layers in the outline) stalk, has been described in the leaf epidermis of several Rubus species (Fell and Rowson 1961). Glandular trichomes produce bioactive substances with various properties for pharmaceutical and industrial applications (Kjær et al. 2012; Tozin et al. 2017; Chwil and Kostryco 2018; Chwil et al. 2013; Mayer et al. 2013; Weryszko-Chmielewska and Chwil 2017). Excretion from a periplasmic space of the upper cell layers pass through the cell wall, accumulate in the subcuticular cavity, and rupture it (Muravnik et al. 2019). Depending on the function, each morphotype of these glands is characterised by varied responses in the defence of plants against environmental factors (Tozin et al. 2017; De Vargas et al. 2019). It has been found that the characteristics of trichomes and stomata are associated with immunity of mulberry to powdery mildew and can be indicators of this type of immunity in cultivation programs (Chattopadhyay et al. 2011).

A stable trait of trichomes in some $R$. idaeus cultivars was used in genetic engineering to develop new varieties (Upadhyaya and Furness 1998). The cultivation work resulted in identification of chromosomal regions of genes encoding and regulating micromorphological traits that can be genetically controlled (Graham et al. 2014). Therefore, some species with favourable traits, e.g. $R$. canescens, are often used in the development of new taxa (Tomaszewski et al. 2014).

Kellogg et al. (2011) suggest that the glandular trichomes of $R$. idaeus give rise to prickle primordia, which transform into thorns. A proportional relationship was found between the size of the trichome heads and the size of the developing thorns. In the present study, thorns were produced by the 'Laszka' and 'Radziejowa' cultivars, which had glandular trichomes, whereas the thornless 'Glen Ample' cultivar had no glandular trichomes. The presence of mechanical and glandular trichomes on the surface of the leaf epidermis was detected in many species from the genus Rubus (Fell and Rowson 1961).

\section{Histochemistry}

The histochemical assays helped to identify various groups of biologically active compounds. The Nadi reagent 


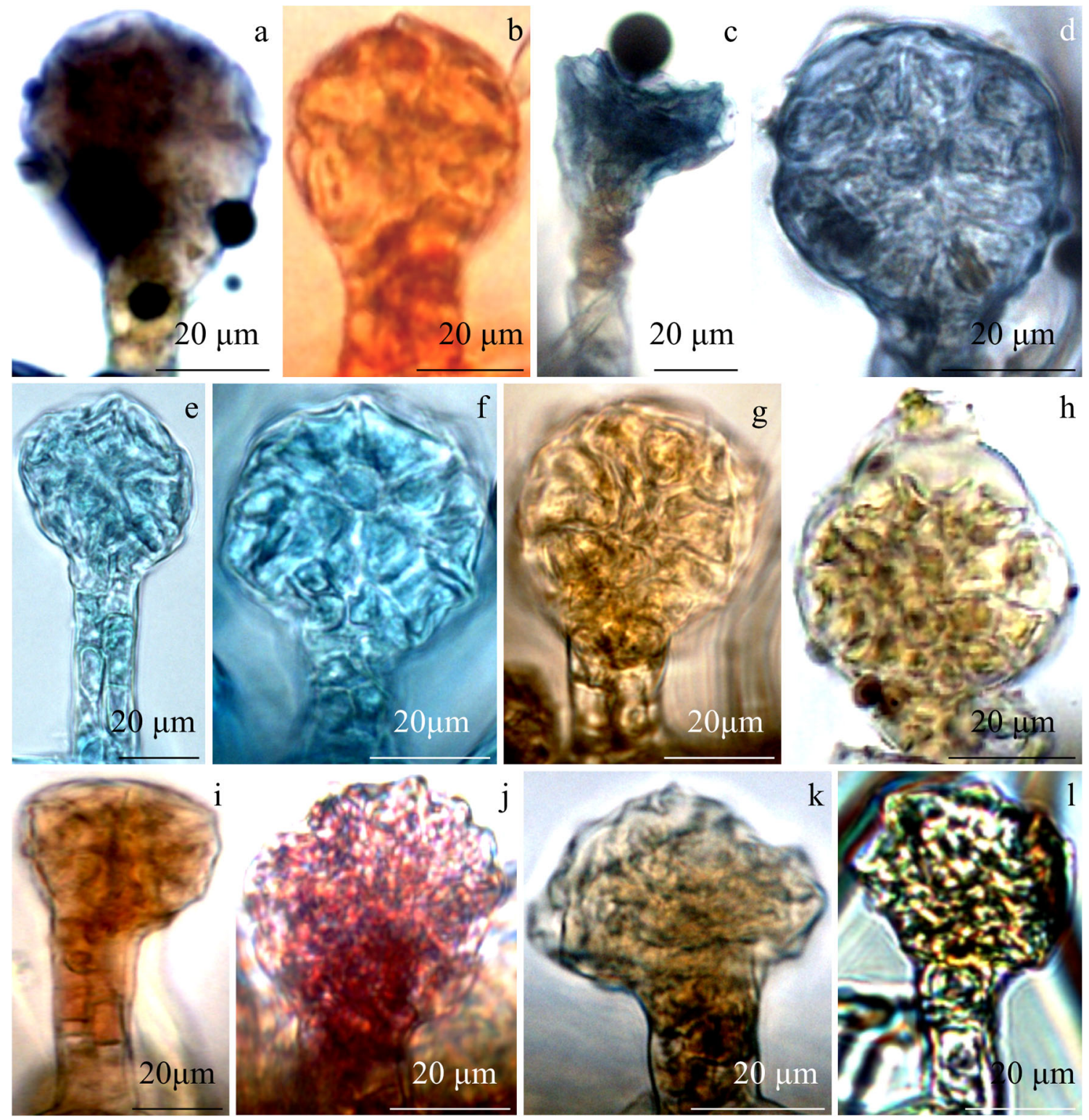

Fig. 8 Histochemistry of glandular trichomes in the adaxial epidermis of $R$. idaeus 'Laszka' and 'Radziejowa' leaves. a Terpene compounds stained dark purple (Nadi reagent). b Lipid-positive staining reaction (red) (Sudan Red 7B). c, d Lipid compounds stained dark blue (Sudan Black B). e, f Acid lipids stained blue (Nile blue). g, h Pectin compounds

stained terpene compounds purple. A similar colour of terpenes was also detected in Rosa $\times$ damascena trichomes (Caissard et al. 2005). This group of compounds in Rubus suavissimus was represented by the dominant rubusoside and steviol monoside (Chou et al. 2009). Another chemotaxonomic function is served by diterpene glycosides identified in R. chingii leaves (Chou et al. 1987).

Lipid compounds in the trichomes were stained red, dark blue, or light blue using Sudan Red 7B, Sudan Black B, or Nile blue, respectively. The compounds were characteristically stained in the trichome secretory head and stalk. stained yellow (Lugol's solution). i Carbohydrates stained brown-red (Fehling's reagent). j Polysaccharides stained pink (periodic acid/Schiff reagent). k Polyphenolic compounds stained brown (potassium dichromate) or black (iron chloride)

A positive result of histochemical assays of the presence of lipids in glandular trichomes was reported in the case of Melissa officinalis (Chwil et al., 2016). In our previous study of Rubi folium from 'Laszka', 'Radziejowa', and 'Glen Ample, the fatty acids were dominated by palmitic, arachidonic, tetracosanoic, and stearic acids. The main omega 3, omega 6 , and omega 9 acids were $\alpha$-linolenic acid, linolenic acid, and oleic acid, respectively (Chwil and Kostryco 2018).

A substantial proportion of fat is contained in epicuticular wax. These are mainly long-chain aliphatic compounds and terpenyl esters ( $\alpha$ - and $\beta$-amyrin and cycloartenol). By forming the structure of wax, these compounds provide 
Table 2 Histochemical tests of the main groups of biologically active compounds in glandular trichomes of the leaves of the three $R$. idaeus varieties

\begin{tabular}{llll}
\hline Target compound & Reagent & Colour observed & Glandular trichomes \\
\hline Nadi reagent & Terpenoids & Purple & + \\
& Essential oils & Violet-blue & + \\
Sudan Red & Lipids & Red & + \\
Sudan Black B & Lipids & Dark blue & + \\
Nile blue A & Acidic lipids & Blue & + \\
Lugol's solution & Proteins & Yellow & + \\
Fehling's reagent & Sugars & Brown-red & + \\
PAS reagent & Polysaccharides & Pink & + \\
Iron chloride & Phenolic compounds & Brown & + \\
Potassium dichromate & Phenolic compounds & Black & + \\
\hline
\end{tabular}

+ indicates positive

protection against some organisms (Shepherd et al. 1999). A similar role of metabolic resistance to pathogens is played by the proteins identified in R. idaeus leaves (Colditz et al. 2007; Hukkanen et al. 2008).

A positive (yellow) staining reaction of protein compounds in the stalk and the secretory head was exhibited after application of Lugol's solution. On average, this group of compounds accounted for $20 \%$ of air-dried matter of $R$. idaeus leaves (Chwil and Kostryco 2018). Proteins exhibit developmental dependence (De Nardi et al. 2006). They can bind hydrophobic ligands (flavonoids and plant hormones) (Fernandes et al. 2008; Mogensen et al. 2007) and serve as flavonoid-type transporters (Hjernø et al. 2006).

Carbohydrates were stained brown-red with Fehling's reagent, whereas the PAS reaction stained polysaccharides pink. These compounds yielded a positive staining reaction in the glandular trichomes in M. officinalis (Chwil et al. 2016). The average content of absorbable carbohydrates and sugars in the leaves of the analysed species was $6 \%$ and $5 \%$, respectively, as reported in the literature. In turn, total fibres constitute $58 \%$ with $4 \mathrm{~g} / 100 \mathrm{~g}$ of the soluble fraction and $54 \mathrm{~g} / 100 \mathrm{~g}$ of the insoluble fraction (Chwil and Kostryco 2018). Extracts of raw $R$. suavissimus leaves were reported to contain $11 \%$ of polysaccharides (Koh et al. 2009). Sugars detected in $R$. chingii were represented by rhamnose, arabinose, xylose, glucose, and galactose. These bioactive compounds isolated from the leaves of this species exhibited antioxidant, anti-inflammatory, and anticancer activity (MCF-7 and Bel-7402). Given their bioactivity, these compounds can be a source of food additives (Zhang et al. 2015).

As in other literature reports, polyphenolic compounds analysed in the present study were stained black or brown with potassium dichromate or iron chloride respectively (Jachuła et al. 2018). In various Rubus species, these compounds have been reported to exhibit antioxidant capacity determined with in vivo and in vitro methods (Dall'Acqua et al. 2008; Chwil and Kostryco 2018). The antioxidant group was dominated by caffeic acid, ferulic acid, quercetin, kaempferol, chlorogenic acid, caffeoylquinic acid (Dall'Acqua et al. 2008). The highest total antioxidant activity in the leaves of the analysed $R$. idaeus cultivars determined with the FRAP and FolinCiocalteu methods was found for 'Radziejowa' (Chwil and Kostryco 2018). The concentration of phenolic compounds in the leaf extracts from the different Rubus species was significantly correlated with the antioxidant activity (Oszmiański et al. 2015; Om et al. 2016). Szymanowska et al. (2018) reported antioxidant and anti-inflammatory properties of phenolic compounds and anthocyanins contained in $R$. idaeus fruit extracts. Their anti-inflammatory action was manifested by an inhibitory effect on the activity of lipoxygenase and cyclooxygenase- 2 in vitro. These extracts effectively inhibited the viability of human leukaemia cells J45 and HL60 in in vitro investigations of cytotoxic activity. As demonstrated
Table 3 Size of stomata in the abaxial epidermis in the three R. idaeus cultivars

\begin{tabular}{llll}
\hline Trait $(\mu \mathrm{m})$ & \multicolumn{2}{l}{ Cultivar } & \\
\cline { 2 - 4 } & $\begin{array}{l}\text { 'Glen Ample' (2n) } \\
\text { Mean } \pm \text { SD }\end{array}$ & 'Laszka' (2n) & 'Radziejowa '(2n) \\
\hline Length of stomata & $17.7 \pm 2.6^{\mathrm{b}}$ & $10.0 \pm 1.2^{\mathrm{c}}$ & $21.8 \pm 2.9^{\mathrm{a}}$ \\
Width of stomata & $16.2 \pm 0.6^{\mathrm{b}}$ & $7.8 \pm 0.6^{\mathrm{c}}$ & $19.4 \pm 1.3^{\mathrm{a}}$ \\
Thickness of cuticular ledge & $3.0 \pm 0.5^{\mathrm{a}}$ & $2.7 \pm 1.1^{\mathrm{b}}$ & $1.7 \pm 0.3^{\mathrm{c}}$ \\
Length of the groove between cuticular ledges & $9.5 \pm 1.1^{\mathrm{b}}$ & $5.3 \pm 0.7^{\mathrm{c}}$ & $11.6 \pm 1.4^{\mathrm{a}}$ \\
\hline
\end{tabular}

Means followed by the same letter are not significantly different between cultivars $(p \leq 0.05)$ 
Fig. 9 Fragments of cross sections of $R$. idaeus 'Glen Ample' (c) 'Laszka' (a, d), and 'Radziejowa' (b, e, f) leaves. a, b Non-glandular (double arrowhead) and glandular (double arrows) trichomes, large abaxial epidermis cells (eb) and smaller adaxial epidermis cells (ed), hypodermal cells (h), palisade parenchyma cells (p), and small spongy parenchyma cells (sp) with numerous plastids and vascular bundle elements (vb) (a). c Midrib and calcium oxalate druses (arrows). $\mathbf{d}-\mathbf{f}$ Sections of 'Glen Ample', 'Laszka', and 'Radziejowa' leaves are visible abaxial epidermis cells (eb) and smaller adaxial epidermis cells (ed), one or two layers of palisade parenchyma cells (p), and spongy parenchyma cells (sp) with numerous plastids, vascular bundle (vb), and stomata (s) located above the epidermis cells
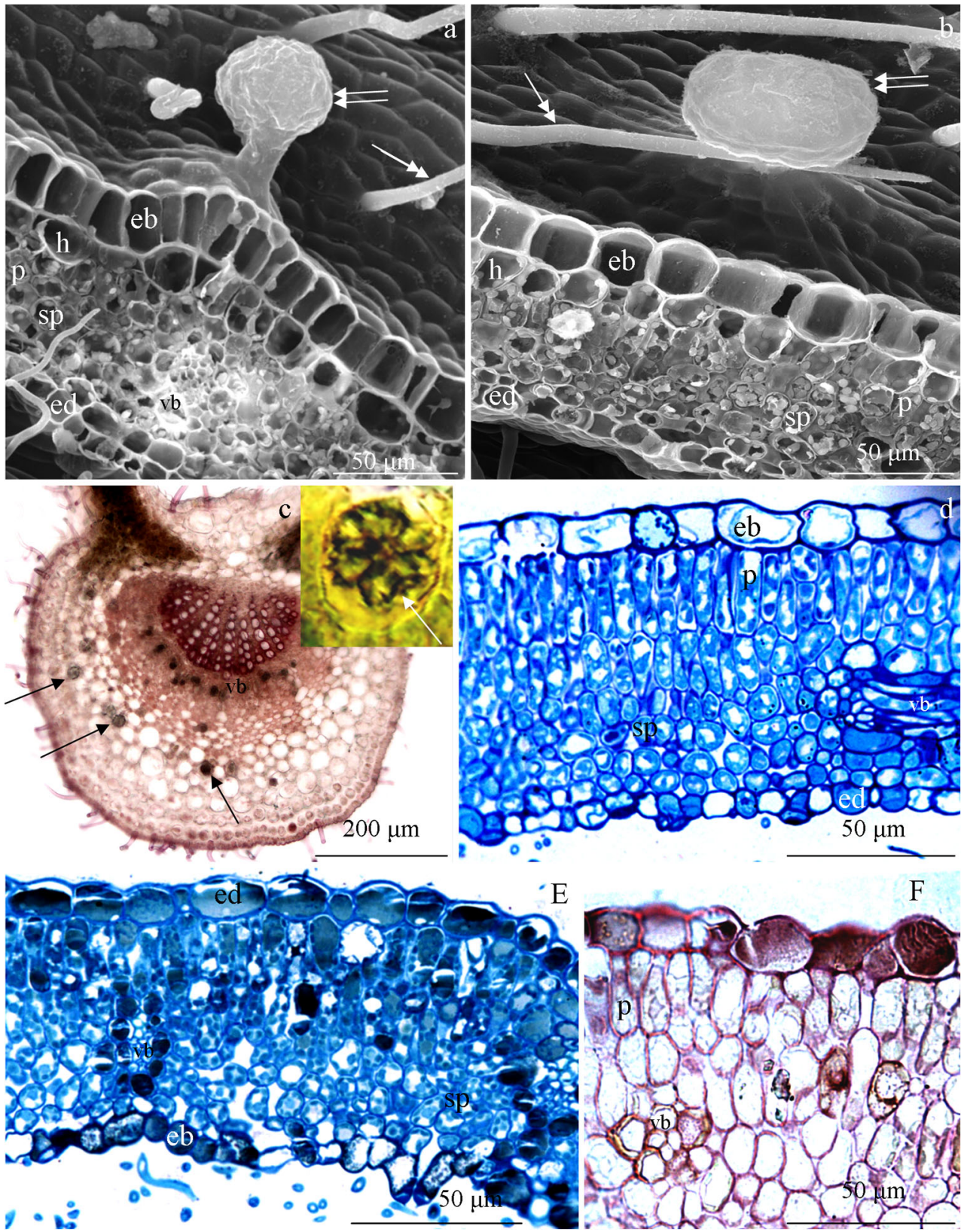

E

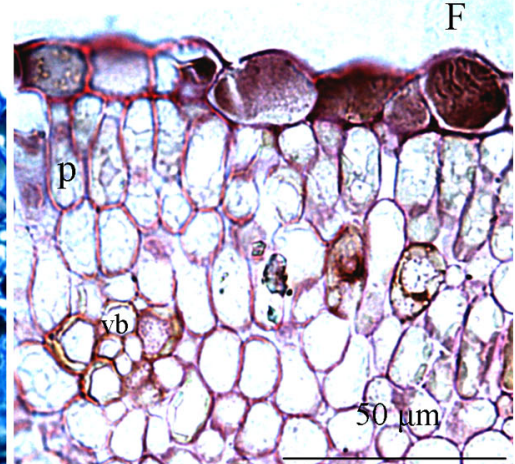

by Manríquez-Torres et al. (2016), fruits of various Rubus species exhibited high antioxidant activity due to their content of anthocyanins and other antioxidants.

\section{Anatomy}

The epidermis of the examined leaves was formed of large cells with a thick outer wall and a cuticle layer. The palisade parenchyma cells formed two layers. A similar number of palisade parenchyma layers were found in the leaves of $R$. idaeus and Prunus serotina (Fell and Rowson 1961; Ferdinand et al. 2000), wherein $R$. idaeus cultivars had a more pronounced double palisade parenchyma than the wild taxa. The size of the palisade parenchyma cells in the present studies is in the range of values specified for $R$. idaeus in literature reports (Fell and Rowson 1960). These traits are ecological adaptations to environmental conditions allowing more efficient utilization of solar radiation (Kołodziejek et al. 2015).

The distribution of mesophyll cells in these leaves and leaves of plants from the genera Sorbus and Pyrus described in the literature indicated a bifacial type (Zamani et al. 2008; Krivoruchko and Gamulya 2013). A well-developed palisade parenchyma determines efficient photosynthesis and is an ecological strategy of adaptation to environmental conditions. This parenchyma utilises solar light more efficiently than the spongy tissue. Plants from insolated habitats are characterised by a well-developed palisade parenchyma. In turn, the amount of the spongy parenchyma increases in shaded environments 
Table 4 Size of epidermis and mesophyll cells on the leaves of the three $R$. idaeus cultivars

\begin{tabular}{lllll}
\hline Trait $(\mu \mathrm{m})$ & & $\begin{array}{l}\text { 'Glen Ample' } \\
\text { Mean } \pm \text { SD }\end{array}$ & 'Laszka' & 'Radziejowa' \\
\hline Height of epidermis cells & Adaxial & $19.1 \pm 6.6^{\mathrm{a}}$ & $16.4 \pm 3.7^{\mathrm{a}}$ & $16.8 \pm 4.6^{\mathrm{a}}$ \\
& Abaxial & $9.4 \pm 3.7^{\mathrm{a}}$ & $9.8 \pm 2.3^{\mathrm{a}}$ & $14.2 \pm 4.3^{\mathrm{b}}$ \\
Width of epidermis cells & Adaxial & $23.9 \pm 6.3^{\mathrm{a}}$ & $22.1 \pm 8.9^{\mathrm{a}}$ & $16.5 \pm 3.0^{\mathrm{b}}$ \\
& Abaxial & $9.9 \pm 1.7^{\mathrm{a}}$ & $13.6 \pm 3.1^{\mathrm{b}}$ & $12.4 \pm 2.4^{\mathrm{b}}$ \\
Height of palisade parenchyma cells & $35.1 \pm 3.1^{\mathrm{a}}$ & $24.6 \pm 2.1^{\mathrm{c}}$ & $28.5 \pm 5.0^{\mathrm{b}}$ \\
Width of palisade parenchyma cells & $7.0 \pm 1.5^{\mathrm{c}}$ & $7.7 \pm 2.1^{\mathrm{b}}$ & $9.3 \pm 2.0^{\mathrm{a}}$ \\
Thickness of parenchyma & Palisade & $51.9 \pm 7.4^{\mathrm{a}}$ & $42.1 \pm 5.5^{\mathrm{b}}$ & $51.4 \pm 4.7^{\mathrm{a}}$ \\
& Spongy & $38.6 \pm 7.6^{\mathrm{a}}$ & $37.9 \pm 5.4^{\mathrm{a}}$ & $40.8 \pm 5.5^{\mathrm{a}}$ \\
Thickness of lamina & & $125.3 \pm 5.3^{\mathrm{a}}$ & $104.7 \pm 8.6^{\mathrm{b}}$ & $121.4 \pm 6.4^{\mathrm{a}}$ \\
\hline
\end{tabular}

Means followed by the same letter are not significantly different between cultivars $(p \leq 0.05)$
(Kołodziejek et al. 2015). The anatomical structure exhibited the presence of numerous calcium oxalate crystals located in a particularly large number close to a large vascular bundle in the leaf midrib. These precipitates have been described in leaves of several species from the genus Rubus (Fell and Rowson 1960, 1961).
Fig. 10 Fragments of cross sections of the cells of adaxial epidermis and assimilation parenchyma in $R$. idaeus 'Radziejowa' leaves. a Adaxial epidermis and palisade mesophyll cells, thick cell walls (arrow) and a large central vacuole (v) in the epidermis cells, numerous plastids (p), large cell nucleus (n) with dense nucleoplasm, nucleolus, and varied degree of vacuolization in assimilation cells. b Epidermis cells, periclinal outer cell wall (cw), cytoplasm, and vacuole (v). c, d Epidermis cells, cuticle strand (c), the other part of the cell wall (cw), and cytoplasm. d Single mitochondria in the epidermis protoplast (asterisk) and mitochondria clustered in the assimilation cell (double asterisk)
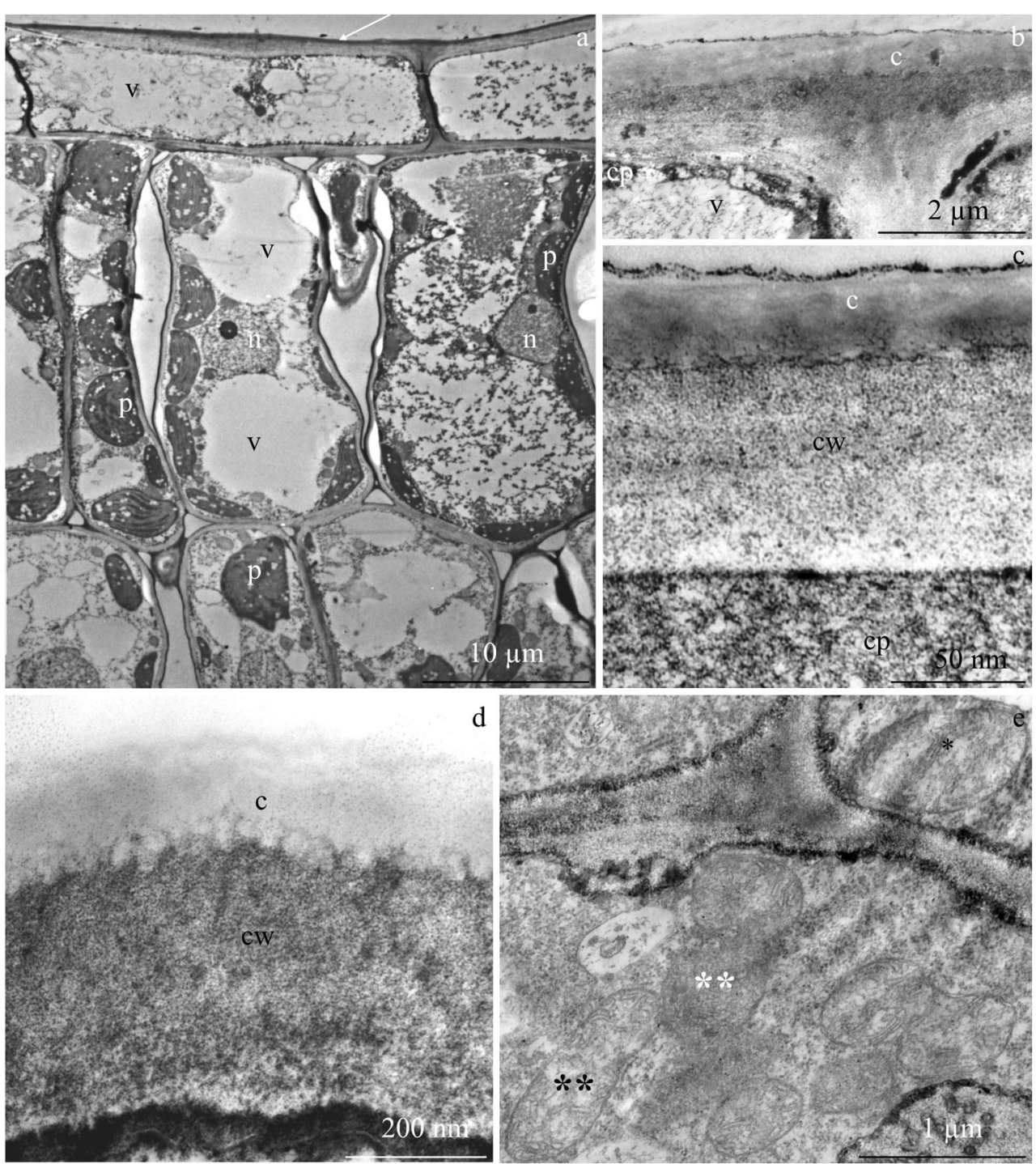
Fig. 11 Fragments of the cross sections of palisade mesophyll cells in R. idaeus 'Radziejowa' leaves. a Protoplast with parietal cytoplasm, which is a visible plastid (p), mitochondria (m), and Golgi apparatus. b, c Plastids (p) with a thylakoid system. c Mitochondrion. d, e Golgi apparatus $(\mathrm{G})$ with cisternae and dictiosomal vesicles
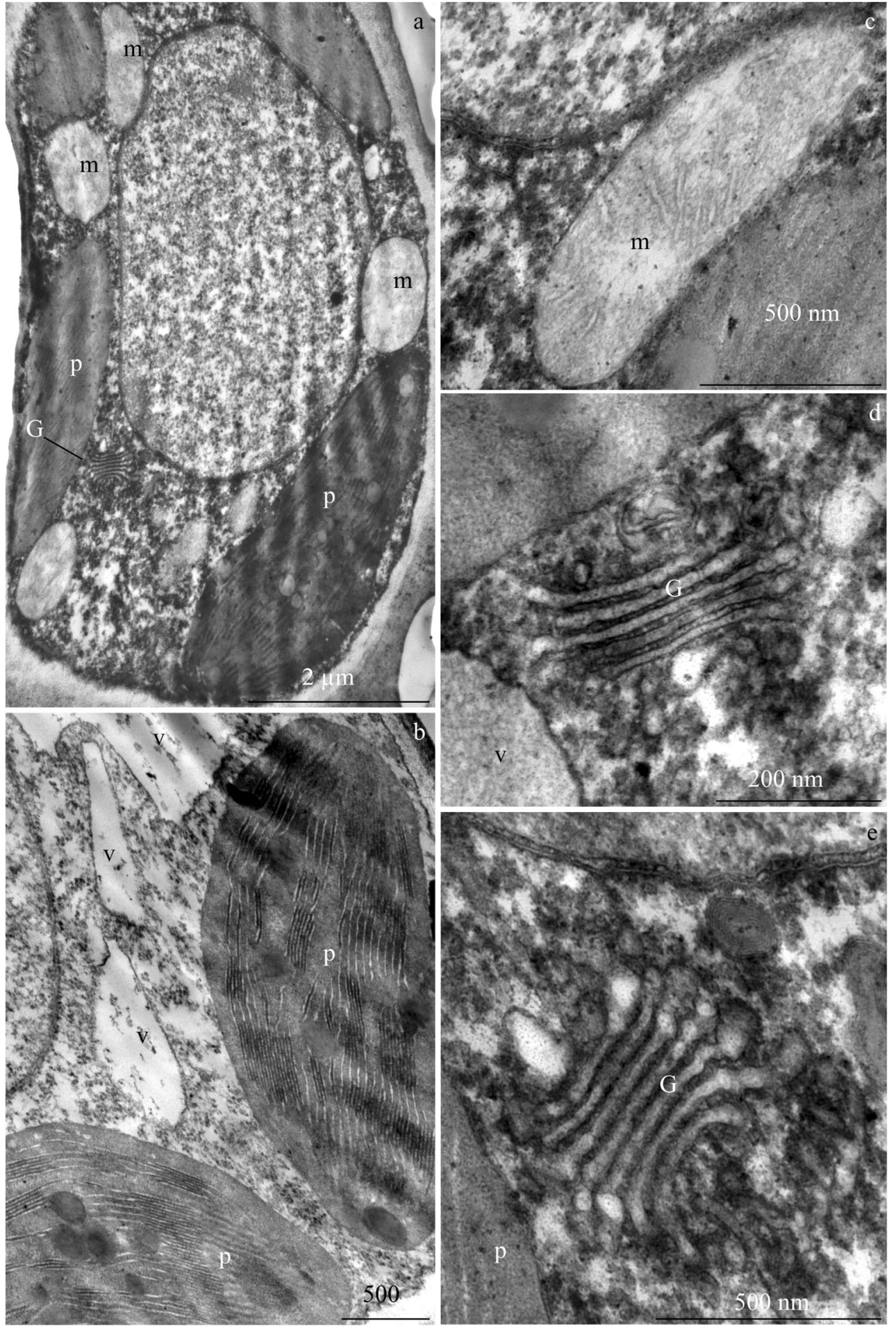

\section{Content of elements}

The content of elements in raspberry leaves largely depends on the mode of cultivation and the environment. Potassium and calcium followed by magnesium and phosphorus dominated in the leaves of the analysed raspberry cultivars. This is evidenced by the large variation of the quantities of these elements in the leaves of raspberry cultivated in different remote regions of Lublin Province, south-eastern Poland (Dresler et al. 2015). The results of the $\mathrm{K}, \mathrm{Mg}$, and P content presented in this study are within the ranges specified by the aforementioned authors for these elements, i.e. K (10,600$20,500 \mathrm{mg} / \mathrm{kg}), \mathrm{Mg}(2600-4500 \mathrm{mg} / \mathrm{kg})$, and P (1900$3000 \mathrm{mg} / \mathrm{kg}$ ), in $R$. idaeus leaves. In turn, the concentration 
Fig. 12 Content of selected elements in the cuticle and other parts of the cell wall of epidermal cells in the leaves of the three R. idaeus cultivars

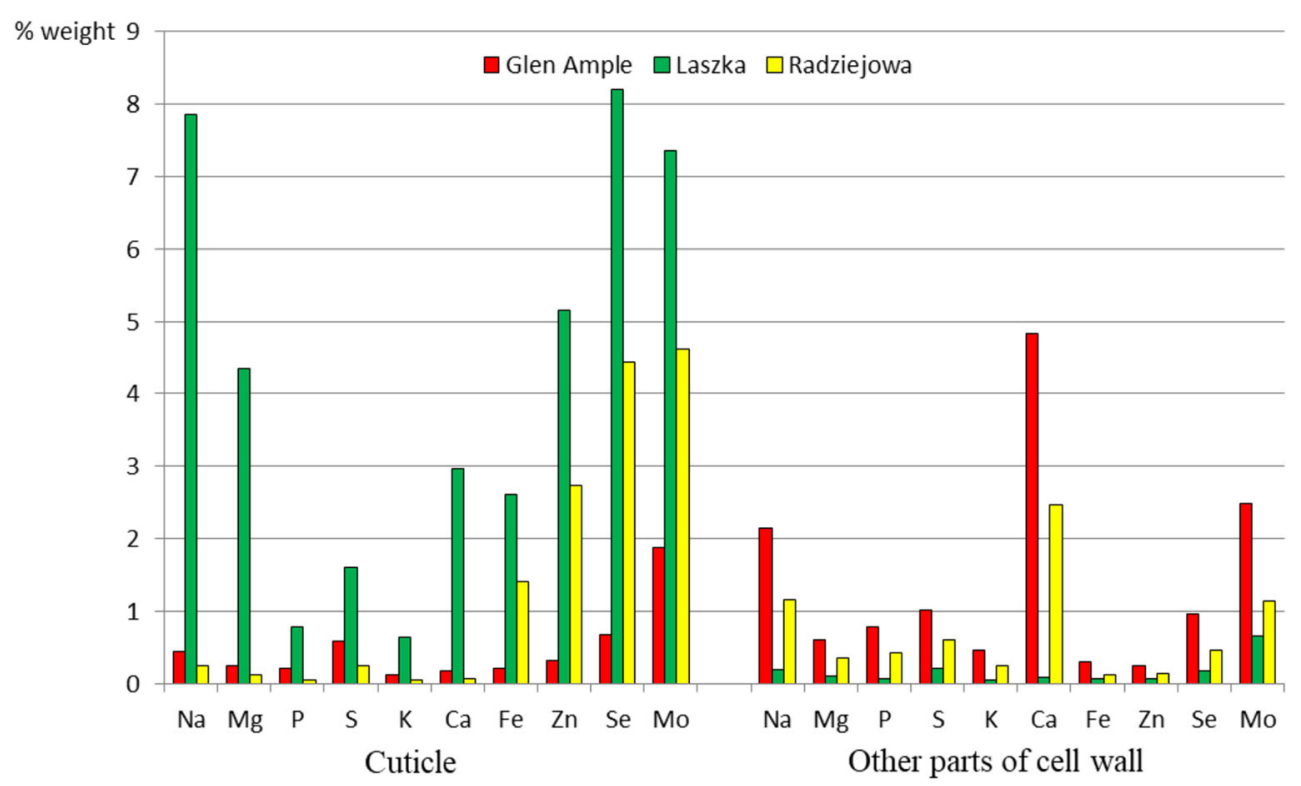

of $\mathrm{Ca}(2610-4800 \mathrm{mg} / \mathrm{kg})$ determined in this study is lower than the content of this element $(7200-15500 \mathrm{mg} / \mathrm{kg})$ in the raw material collected by these researchers. These mineral elements are components of enzymes and proteins as well as important elements of biochemical processes and tissue structures in the human organism (Higdon 2003).

Assessment of the nutritional value in terms of the content of elements in the leaves of the raspberry cultivars analysed in this study can be based on comparison of their concentrations in the leaves of different Camellia sinensis cultivars. The $\mathrm{Ca}$, $\mathrm{Mg}, \mathrm{Cu}, \mathrm{Fe}$, and $\mathrm{Zn}$ content reported in the present study was similar or higher, the amount of $\mathrm{K}$ and $\mathrm{P}$ was in the same range, and the level of $\mathrm{Na}, \mathrm{Pb}$, and $\mathrm{Cd}$ was lower as compared with that in green tea leaves. In turn, the Fe content in the examined $R$. idaeus cultivars was substantially higher than the concentration of this element in Camellia sinensis leaves (Chen et al. 2009). Milošević et al. (2018) reported that blackberry fertilization with NPK, manure, natural zeolite, and their mixtures changed a majority of cane and berry physical traits and leaf nutrient status. Increased meso-nutrients improve the growth of micropropagated red raspberries. The ratio of ammonium to nitrate varies greatly for improving plant growth. An important step is to determine the driving mineral factors in improved medium formulations for micropropagated red raspberries (Poothong and Reed 2014).

The content of $\mathrm{Ca}$ in our studies were from half to threefold lower than that in leaf blades in $R$. coreanus. In turn, the content of $\mathrm{K}$ was lower in 'Glen Ample', equal in
Fig. 13 Content of selected elements in the cytoplasm and vacuole of epidermal cells in the leaves of the three $R$. idaeus cultivars

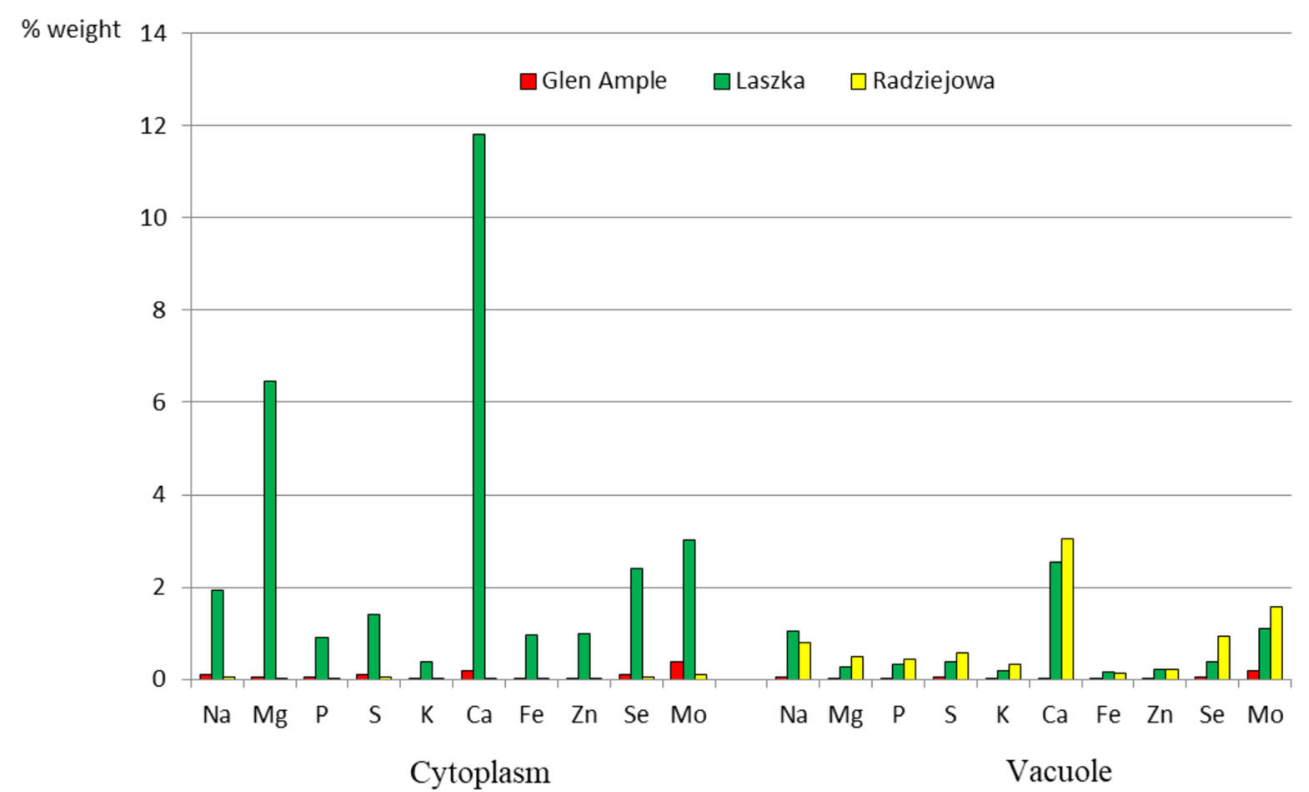


Table 5 The content of elements in the leaves of the three varieties of $R$. idaeus

\begin{tabular}{llll}
\hline Element content & $\begin{array}{l}\text { 'Glen Ample' } \\
\text { Mean } \pm \text { SD }(\mathrm{mg} / \mathrm{kg})\end{array}$ & 'Laszka' & \\
\hline Potassium & $12,600 \pm 100^{\mathrm{c}}$ & $20,000 \pm 298^{\mathrm{a}}$ & $14,100 \pm 203^{\mathrm{b}}$ \\
Calcium & $4800 \pm 159^{\mathrm{a}}$ & $2730 \pm 155^{\mathrm{b}}$ & $2610 \pm 82^{\mathrm{b}}$ \\
Magnesium & $2800 \pm 109^{\mathrm{b}}$ & $2100 \pm 115^{\mathrm{c}}$ & $3610 \pm 121^{\mathrm{a}}$ \\
Phosphorus & $2550 \pm 239^{\mathrm{a}}$ & $2463 \pm 190^{\mathrm{ab}}$ & $2090 \pm 146^{\mathrm{b}}$ \\
Iron & $176 \pm 16^{\mathrm{c}}$ & $208 \pm 18^{\mathrm{b}}$ & $252 \pm 19^{\mathrm{a}}$ \\
Sodium & $<0.250^{\mathrm{a}}$ & $<0.250^{\mathrm{a}}$ & $<0.250^{\mathrm{a}}$ \\
Copper & $12 \pm 1^{\mathrm{b}}$ & $34 \pm 1^{\mathrm{a}}$ & $11 \pm 0.4^{\mathrm{b}}$ \\
Zinc & $34 \pm 3^{\mathrm{a}}$ & $40 \pm 3^{\mathrm{a}}$ & $40 \pm 3^{\mathrm{a}}$ \\
Lead & $0.0018 \pm 0.0001^{\mathrm{b}}$ & $0.0021 \pm 0.0003^{\mathrm{ab}}$ & $0.0023 \pm 0.0002^{\mathrm{a}}$ \\
Cadmium & $0.0026 \pm 0.0003^{\mathrm{a}}$ & $0.0029 \pm 0.0003^{\mathrm{a}}$ & $0.0007 \pm 0.0001^{\mathrm{b}}$ \\
\hline
\end{tabular}

Means followed by the same letter are not significantly different between cultivars $(p \leq 0.05)$
'Radziejowa', and greater in 'Laszka' than in $R$. coreanus. In leaves 'Glen Ample' and 'Radziejowa', the higher $\mathrm{Mg}$ and $\mathrm{Cu}$ as well as lower content than that in $R$. coreanus was found (Om et al. 2016).

The content of trace elements, i.e. cadmium $(0.0007-$ $0.0029 \mathrm{mg} / \mathrm{kg}$ ) and lead $(0.0018-0.0023)$, in the examined $R$. idaeus leaves was significantly lower than the permissible levels specified for plant raw materials (Wang et al. 2015). Lead and cadmium are very harmful to humans (Grytsyuk et al. 2006). Lead is toxic to the circulatory, nervous, and digestive systems and accumulates in bones (Glenn et al. 2001; Gidlow 2004). In turn, cadmium damages kidneys, bones, and the respiratory system (Godt et al. 2006). The content of $\mathrm{Cd}$ and $\mathrm{Pb}$ in the leaves of the $R$. idaeus cultivars analysed in the present study and described in the literature (Cd $0.0026 \mathrm{mg} / \mathrm{kg}, \mathrm{Pb} 0.0018-0.0023 \mathrm{mg} / \mathrm{kg}$ ) is substantially lower than that in Camellia sinensis leaves $(\mathrm{Cd} 0.05 \mathrm{mg} / \mathrm{kg}$, $\mathrm{Pb} 2.28-4.33 \mathrm{mg} / \mathrm{kg}$ ) (Chen et al. 2009). This indicates that the raspberry shrubs analysed in this study grow on unpolluted and uncontaminated soil in the clean environment of the Lublin Upland located in the east-south of Poland.

\section{Conclusions}

The knowledge of the micromorphology and anatomy of glandular trichomes, which are present in the vegetative parts of plants from the family Rosaceae, is highly important in the verification of the authenticity of herbal raw material. The present study provides information in the field of plant biology, more specifically botany, regarding glandular trichomes as a site of accumulation of secondary metabolites used e.g. in pharmaceutical, food, cosmetics, and chemical industries. These phytochemicals play a key role in plant communication with the environment, including plant-animal interactions, the ecology of pollination, and plant protection against unfavourable environmental factors. This important scientific information can be used in agricultural and horticultural practice by herbalists, dieticians, pharmacists, cosmetologists, and beauticians.

The glandular trichomes with a multicellular head and a multilayer stalk were present on the epidermis in 'Laszka' and 'Radziejowa'. The micromorphology of the abaxial Rubus idaeus epidermis exhibited a striated or smooth cuticle, stomata located above the other epidermis cells, and characteristic long, twisted non-glandular trichomes. The densely growing non-glandular trichomes may have a relaxing function, preventing clumping of mixed raw materials in herbal mixtures. The groups of bioactive compounds, polyphenols, terpenes, lipids, proteins, and carbohydrates, were identified in the $R$. idaeus glandular trichomes using histochemical assays. Given the bioactivity as well as antimicrobial and antioxidant activity of the compounds, the leaves of this species can be a source of bioactive compounds. The $R$. idaeus leaves are classified as hypostomatic and bifacial. At the ultrastructure level of the leaf cells of the analysed cultivars, the highest concentrations were detected in the case of $\mathrm{Na}, \mathrm{Ca}, \mathrm{Se}$, and Mo. While K, Ca, Mg, P, and Fe were the dominant elements in the leaf dry mass of the analysed cultivars. Infusions from raspberry leaves are safe for health in terms of the $\mathrm{Cd}$ and $\mathrm{Pb}$ concentrations, well below the permissible level. Raspberry leaves can be a valuable raw material for preparation of infusions due to the high content of nutrient elements.

Further investigations should be continued to search for bioactive compounds with antiviral, antibacterial, antifungal, antineoplastic, and anti-inflammatory activities in the leaves of the new varieties of Rubus idaeus, which adapt well to specific areas of cultivation. The challenge is to apply environmental modifications as well as agrotechnical and genetic engineering methods for modification of the composition of glandular secretions and thus improve the quality of the raw material. 
Sources of funding The research was supported by the Ministry of Science and Higher Education of Poland in part of the statutory activities of University of Life Sciences in Lublin.

Contributions by the authors M.Ch. is responsible for the conceptualization, microscopic observations, writing the original draft, and revision and editing of the manuscript. M.Ch. and M.K. are responsible for the data curation, formal analysis, investigation, and methodology.

\section{Compliance with ethical standards}

Conflict of interest The authors declare that they have no conflicts of interest.

Open Access This article is distributed under the terms of the Creative Commons Attribution 4.0 International License (http:// creativecommons.org/licenses/by/4.0/), which permits unrestricted use, distribution, and reproduction in any medium, provided you give appropriate credit to the original author(s) and the source, provide a link to the Creative Commons license, and indicate if changes were made.

\section{References}

Ahmad M, Masood S, Sultana S, Hadda TB, Bader A, Zafar M (2015) Antioxidant and nutraceutical value of wild medicinal Rubus berries. Pak J Pharm Sci 28:241-247

Ali L, Svensson B, Alsanius BW, Olsson ME (2011) Late season harvest and storage of Rubus berries - major antioxidant and sugar levels. Sci Hortic 129:376-381. https://doi.org/10.1016/j.scienta.2011.03.047

Amrehn E, Heller A, Spring O (2014) Capitate glandular trichomes of Helianthus annuus (Asteraceae): ultrastructure and cytological development. Protoplasma 251:161-167. https://doi.org/10.1007/ s00709-013-0534-7

Aybastıer Ö, Ișık E, Șahin S, Demir C (2013) Optimization of ultrasonicassisted extraction of antioxidant compounds from blackberry leaves using response surface methodology. Ind Crop Prod 44: 558-565. https://doi.org/10.1016/j.indcrop.2012.09.022

Ayoola GA, Coker HA, Adesegun SA, Adepoju-Bello AA, Obaweya K, Ezennia EC, Atangbayila TO (2008) Phytochemical screening and antioxidant activities of some selected medicinal plants used for malaria therapy in southwestern Nigeria. Trop J Pharm Res 7: 1019-1024. https://doi.org/10.4314/tjpr.v7i3.14686

Brundrett MC, Kendrick B, Peterson CA (1991) Efficient lipid staining in plant material with Sudan Red 7B or Fluoral Yellow 088 in polyethylene glycol-glycerol. Biotech Histochem 66:111-116. https://doi. org/10.3109/10520299109110562

Buřičová L, Andjelkovic M, Čermáková A, Zuzana R, Ondřej J, Kolehmainen E, Verhé R, Kvasnička F (2011) Antioxidant capacities and antioxidants of strawberry, blackberry and raspberry leaves. Czech J Food Sci 29:181-189

Caissard JC, Bergougnoux V, Martin M, Mauriat M, Baudino S (2005) Chemical and histochemical analysis of 'Quatre Saisons Blanc Mousseux', a moss rose of the Rosa $\times$ damascena group. Ann Bot 97:231-238. https://doi.org/10.1093/aob/mcj034

Chattopadhyay S, Ali KA, Doss SG, Das NK, Aggarwal RK, Bandopadhyay TK, Sarkar A, Bajpai AK (2011) Association of leaf micro-morphological characters with powdery mildew resistance in field-grown mulberry (Morus spp.) germplasm. AoB Plants 2011: plr002. https://doi.org/10.1093/aobpla/plr002

Chen Y, Yu M, Xu J, Chen X, Shi J (2009) Differentiation of eight tea (Camellia sinensis) cultivars in China by elemental fingerprint of their leaves. J Sci Food Agric 89:2350-2355. https://doi.org/10. $1002 /$ jsfa.3716

Chou WH, Oinaka T, Kanamaru F, Mizutani K, Chen FH, Tanaka O (1987) Diterpene glycosides from leaves of Chinese Rubus chingii and fruits of $R$. suavissimus, and identification of the source plant of the Chinese folk medicine "Fu-pen-zi". Chem Pharm Bull 35:30213024. https://doi.org/10.1248/cpb.35.3021

Chou G, Xu SJ, Liu D, Koh GY, Zhang J, Liu Z (2009) Quantitative and fingerprint analyses of Chinese sweet tea plant (Rubus suavissimus S. Lee). J Agric Food Chem 57:1076-1083. https://doi.org/10.1021/ jf8029397

Chwil M, Kostryco (2018) Bioactive compounds and antioxidant activity of Rubus idaeus L. leaves. Acta Sci Pol Hortorum Cultus 17:135148. https://doi.org/10.24326/asphc.2018.2.12

Chwil M, Weryszko-Chmielewska E, Sulborska A, Michonska M (2013) Micromorphology of trichomes in the flowers of the horse chestnut Aesculus hippocastanum L. Acta Agrobot 66:45-54. https://doi.org/ 10.5586/aa.2013.050

Chwil M, Nurzyńska-Wierdak R, Chwil S, Matraszek R, Neugebauerová J (2016) Histochemistry and micromorphological diversity of glandular trichomes in Melissa officinalis L. leaf epidermis. Acta Sci Pol Hortorum Cultus 15:153-172

Colditz F, Niehaus K, Krajinski F (2007) Silencing of PR-10-like proteins in Medicago truncatula results in an antagonistic induction of other $\mathrm{PR}$ proteins and in an increased tolerance upon infection with the oomycete Aphanomyces euteiches. Planta 226:57-71. https://doi. org/10.1007/s00425-006-0466-y

Costea T, Vlase L, Gostin IN, Olah NK, Predan GM (2016) Botanical characterization, phytochemical and antioxidant activity of indigenous red raspberry (Rubus idaeus L.) leaves. Studia Universitatis Vasile Goldis. Seria Stiintele Vietii 26:463-472

Dall'Acqua S, Cervellati R, Loi MC, Innocenti G (2008) Evaluation of in vitro antioxidant properties of some traditional Sardinian medicinal plants: investigation of the high antioxidant capacity of Rubus ulmifolius. Food Chem 106:745-749. https://doi.org/10.1016/j. foodchem.2007.06.055

David R, Carde JP (1964) Coloration dieÂrentielle des pseudophylles de Pin maritime au moyen du reÂactif de Nadi. Comptes Rendus Acad SciSeÂrie D 258:1338-1340

De Nardi B, Dreos R, Del Terra L, Martellossi C, Asquini E, Tornincasa P, Gasperini D, Pacchioni B, Rathinavelu R, Pallavicini A, Graziosi G (2006) Differential responses of Coffea arabica L. leaves and roots to chemically induced systemic acquired resistance. Genome 49: 1594-1605. https://doi.org/10.1139/g06-125

De Vargas W, Fortuna-Perez AP, Lewis GP, Piva TC, Vatanparast M, Machado SR (2019) Ultrastructure and secretion of glandular trichomes in species of subtribe Cajaninae Benth (Leguminosae, Phaseoleae). Protoplasma 256:431-445. https://doi.org/10.1007/ s00709-018-1307-0

Dresler S, Bednarek W, Tkaczyk P, Hawrylak-Nowak B (2015) Estimation of the macro- and micronutrient status of raspberries grown in the Lublin region. Folia Hortic 27:53-62. https://doi.org/ 10.1515/fhort-2015-0014

Feder N, O'brien TP (1968) Plant microtechnique: some principles and new methods. Am J Bot 5:123-142

Fell KR, Rowson JM (1960) Anatomical studies in the genus Rubus. Part III. The anatomy of the leaf of Rubus loganobaccus L. H. Bailey. J Pharm Pharmacol 12:473-487. https://doi.org/10.1111/j.2042-7158. 1960.tb12695.x

Fell KR, Rowson JM (1961) Anatomical studies in the genus Rubus. Part IV. Anatomical variations in the leaves of cultivated varietes of $R$. idaeus L. and $R$. loganobaccus L. H. Bailey, and of certain 
species of bramble. J Pharm Pharmacol 13:83-92. https://doi.org/ 10.1111/j.2042-7158.1961.tb11792.x

Ferdinand JA, Fredericksen TS, Kouterick KB, Skelly JM (2000) Leaf morphology and ozone sensitivity of two open pollinated genotypes of black cherry (Prunus serotina) seedlings. Environ Pollut 108: 297-302. https://doi.org/10.1016/S0269-7491(99)00078-0

Fernandes H, Pasternak O, Bujacz G, Bujacz A, Sikorski MM, Jaskolski M (2008) Lupinus luteus pathogenesis-related protein as a reservoir for cytokinin. J Mol Biol 378:1040-1051. https://doi.org/10.1016/j. jmb.2008.03.027

Finn CE, Moore PP, Kempler C (2005) Raspberry cultivars: what's new? What's succeeding? Where are breeding programs heading? Acta Hortic 777:33-40

Gabe M (1968) Techniques histologiques. Masson, Paris

Gallaher RN, Gallaher K, Marshall AJ, Marshall AC (2006) Mineral analysis of ten types of commercially available tea. J Food Compos Anal 19:S53-S57. https://doi.org/10.1016/j.jfca.2006.02.006

Gidlow DA (2004) Lead toxicity. Occup Med 54:76-81. https://doi.org/ 10.1590/S1677-04202005000100004

Glenn BS, Stewart WF, Schwartz BS, Bressler J (2001) Relation of alleles of the sodium-potassium adenosine triphosphate alpha two gene with blood pressure and lead exposure. Am J Epidemiol 153:537545. https://doi.org/10.1093/aje/153.6.537

Godt J, Scheidig F, Grosse-Siestrup C, Esche V, Brandenburg P, Reich A, Groneberg DA (2006) The toxicity of cadmium and resulting hazard for human health. J Occup Med Toxicol 1:1-6. https://doi.org/10. 1186/1745-6673-1-22

Grabek-Lejko D, Wojtowicz K (2014) Comparison of antibacterial and antioxidant properties of fruits and leaves of blackberry (Rubus plicatus) and raspberry (Rubus idaeus L.). J Microbiol Biotechnol Food Sci 3:514-518. https://doi.org/10.1021/j99908345

Graham J, Hackett CA, Smith K, Karley AJ, Mitchell C, Roberts H, O'Neill T (2014) Genetic and environmental regulation of plant architectural traits and opportunities for pest control in raspberry. Ann Appl Biol 165:318-328. https://doi.org/10.1111/aab.12134

Grytsyuk N, Arapis G, Perepelyatnikova L, Ivanova T, Vynograds'ka V (2006) Heavy metals effects on forage crops yields and estimation of elements accumulation in plants as affected by soil. Sci Total Environ 354:224-231. https://doi.org/10.1016/j.scitotenv.2005.01.007

Heslop-Harrison Y, Shivanna KR (1977) The receptive surface of the Angiosperm stigma. Ann Bot 41:1233-1258. https://doi.org/10. 1093/oxfordjournals.aob.a085414

Higdon J (2003) An evidence-based approach to vitamins and minerals. Health implications and intake recommendations. Stuttgart: Thieme, New York

Hjernø K, Alm R, Canbäck B, Matthiesen R, Trajkovski K, Björk L, Roepstorff P, Emanuelsson C (2006) Down-regulation of the strawberry Bet $\mathrm{v}$ 1-homologous allergen in concert with the flavonoid biosynthesis pathway in colorless strawberry mutant. Proteomics 6:1574-1587. https://doi.org/10.1002/pmic.200500469

Hukkanen A, Kokko H, Buchala A, Häyrinen J, Kärenlampi S (2008) Benzothiadiazole affects the leaf proteome in arctic bramble (Rubus arcticus). Mol Plant Pathol 9:799-808. https://doi.org/10.1111/j. 1364-3703.2008.00502.x

Jachuła J, Konarska A, Denisow B (2018) Micromorphological and histochemical attributes of flowers and floral reward in Linaria vulgaris (Plantaginaceae). Protoplasma 255:1763-1776. https://doi.org/10. 1007/s00709-018-1269-2

Jensen WA (1962) Botanical histochemistry: principles and practice. Freeman, William and Jensen, San Francisco

Johansen DA (1940) Plant microtechique. McGraw-Hill Book Company, London

Karley AJ, Mitchell C, Brookes C, McNicol J, O’Neill T, Roberts H, Graham J, Johnson SN (2015) Exploiting physical defence traits for crop protection: leaf trichomes of Rubus idaeus have deterrent effects on spider mites but not aphids. Ann Appl Biol 168:159-172. https://doi.org/10.1111/aab.12252

Kellogg AA, Branaman TJ, Jones NM, Little CZ, Swanson JD (2011) Morphological studies of developing Rubus prickles suggest that they are modified glandular trichomes. Botany 89:217-226

Kjær A, Grevsen K, Jensen M (2012) Effect of external stress on density and size of glandular trichomes in full-grown Artemisia annua, the source of anti-malarial artemisinin. AoB Plants 2012:pls018. https:// doi.org/10.1093/aobpla/pls018

Koh GY, Chou G, Liu Z (2009) Purification of a water extract of Chinese sweet tea plant (Rubus suavissimus S. Lee) by alcohol precipitation. J Agric Food Chem 57:5000-5006. https://doi.org/10.1021/ jf900269r

Kołodziejek J, Glińska S, Michlewska S (2015) Seasonal leaf dimorphism in Potentilla argentea L. var. tenuiloba (Jord.) Sw.(Rosaceae). Acta Bot Croat 74:53-70

Konopiński M, Żuber S (2013) Response of raspberry (Rubus idaeus L.) on soil mulching and foliar nutrition with manganese. Modern Phytomorph 3:119-124. https://doi.org/10.5281/zenodo.162000

Krivoruchko OV, Gamulya OV (2013) The anatomical study of Sorbus aucuparia and Sorbus domestica leaves. New Pharm 4:33-36

Levin DA (1973) The role of trichomes in plant defense. Q Rev Biol 48: $3-15$

Lison L (1960) Principes et méthodes. in histochimie et cytochimie animales. Gauthier-Villars, Paris, pp 745-746

Lusa MG, Cardoso EC, Machado SR, Appezzato-da-Glória B (2015) Trichomes related to an unusual method of water retention and protection of the stem apex in an arid zone perennial species. AoB Plants 7:plu088. https://doi.org/10.1093/aobpla/plu088

Manríquez-Torres JDJ, Sánchez-Franco JA, Ramírez-Moreno E, CruzCansino NDS, Ariza-Ortega JA, Torres-Valencia JM (2016) Effect of thermoultrasound on the antioxidant compounds and fatty acid profile of blackberry (Rubus fruticosus spp.) juice. Molecules 21: 1624. https://doi.org/10.3390/molecules21121624

Mason JB (2007) Vitamins, trace minerals and other micronutrients. In: Goldman L, Ausiello DA (eds) Cecil medicine, 23rd edn. Saunders, Philadelphia, PA, USA, pp 1626-1639

Mayer JLS, Carmello-Guerreiro SM, Mazzafera P (2013) A functional role for the colleters of coffee flowers. AoB Plants 5:plt029. https:// doi.org/10.1093/aobpla/plt029

Milošević TM, Glišić IP, Glišić IS, Milošević NT (2018) Cane properties, yield, berry quality attributes and leaf nutrient composition of blackberry as affected by different fertilization regimes. Sci Hortic 227: 48-56. https://doi.org/10.1016/j.scienta.2017.09.013

Miyashita T, Kunitake H, Yotsukura N, Hoshino Y (2015) Assessment of genetic relationships among cultivated and wild Rubus accessions using AFLP markers. Sci Hortic 193:165-173. https://doi.org/10. 1016/j.scienta.2015.07.004

Mogensen JE, Ferreras M, Wimmer R, Petersen SV, Enghild JJ, Otzen DE (2007) The major allergen from birch tree pollen, Bet $v 1$, binds and permeabilizes membranes. Biochemistry 46:3356-3365. https:// doi.org/10.1021/bi062058h

Mowry RW (1963) The special value of methods that color both acidic and vicinal hydroxyl groups in the histochemical study of mucins. With revised directions for the colloidal iron stain, the use of Alcian blue G8X and their combinations with the periodic acid-Schiff reaction. Ann N Y Acad Sci 106:402-423

Muravnik LE, Kostina OV, Mosina AA (2019) Glandular trichomes of the leaves in three Doronicum species (Senecioneae, Asteraceae): morphology, histochemistry, and ultrastructure. Protoplasma 256:115. https://doi.org/10.1007/s00709-018-01342-2

Naruhashi N, Iwatsubo Y, Peng CI (2002) Chromosome numbers in Rubus (Rosaceae) of Taiwan. Bot Bull Acad Sinica 43:193-201

Om AS, Song YN, Noh G, Kim H, Choe J (2016) Nutrition composition and single, 14-day and 13-week repeated oral dose toxicity studies 
of the leaves and stems of Rubus coreanus Miquel. Molecules 21: 65. https://doi.org/10.3390/molecules21010065

Oszmiański J, Wojdyło A, Nowicka P, Teleszko M, Cebulak T, Wolanin M (2015) Determination of phenolic compounds and antioxidant activity in leaves from wild Rubus L. species. Molecules 20:49514966. https://doi.org/10.3390/molecules20034951

Pansarin ER, Maciel AA (2017) Evolution of pollination systems involving edible trichomes in orchids. AoB Plants 9:plx033. https://doi. org/10.1093/aobpla/plx033

Payne WW (1978) A glossary of plant hair terminology. Brittonia 30: 239-255. https://doi.org/10.2307/2806659

Pilon M, Abdel-Ghany SE, Cohu CM, Gogolin KA, Ye H (2006) Copper cofactor delivery in plant cells. Curr Opin Plant Biol 9:256-263. https://doi.org/10.1016/j.pbi.2006.03.007

Poothong S, Reed BM (2014) Modeling the effects of mineral nutrition for improving growth and development of micropropagated red raspberries. Sci Hortic 165:132-141. https://doi.org/10.1016/j. scienta.2013.10.040

Reynolds RS (1963) The use of lead citrate at high $\mathrm{pH}$ as electron opaque stain in electron microscopy. J Cell Biol 17:208-213

Ribeiro RDA, De Melo MMRF, De Barros F, Gomes C, Trolin G (1986) Acute antihypertensive effect in conscious rats produced by some medicinal plants used in the state of Sao Paulo. J Ethnopharmacol 15:261-269. https://doi.org/10.1016/0378-8741(86)90164-9

Romanowicz A, Krzepiłko A (2013) Comparison of catalase activity in various organs of Rubus idaeus L. raspberry cv Polana and in soil under cultivation thereof determined with the volumetric method [in Polish]. Pol J Agric 15:49-53

Schreiber L, Bach S, Kirsch T, Knoll D, Schalz K, Riederer M (1995) A simple photometric device analysing cuticular transport physiology: surfactant effect on permeability of isolated cuticular membranes of Prunus laurocerasus L. J Exp Bot 46:1915-1921. https://doi.org/10. $1093 / \mathrm{jxb} / 46.12 .1915$

Ścibior D, Czeczot H (2006) Catalase: structure, properties, functions [in Polish]. Postepy Hig Med Dosw 60:170-180

Shepherd T, Robertson GW, Griffiths DW, Birch ANE (1999) Epicuticular wax ester and triacylglycerol composition in relation to aphid infestation and resistance in red raspberry (Rubus idaeus L.). Phytochemistry 52:1255-1267. https://doi.org/10.1016/S00319422(99)00414-8

Song JH, Hong SP (2014) The taxonomic implication of leaf anatomy in tribe Sorbarieae (Spiraeoideae: Rosaceae). Korean J Pl Taxon 44: 119-131. https://doi.org/10.11110/kjpt.2014.44.2.11
Stadtländer CTKH (2007) Scanning electron microscopy and transmission electron microscopy of mollicutes: challenges and opportunities. Mod Res Educ Top Microsc 1:122-131

Szymanowska U, Baraniak B, Bogucka-Kocka A (2018) Antioxidant, anti-inflammatory, and postulated cytotoxic activity of phenolic and anthocyanin-rich fractions from Polana raspberry (Rubus idaeus L.) fruit and juice - In vitro study. Molecules 23:1812. https://doi. org/10.3390/molecules23071812

Tomaszewski D, Zieliński J, Gawlak M (2014) Foliar indumentum in central European Rubus species (Rosaceae) and its contribution to the systematics of the group. Nord J Bot 32:1-10. https://doi.org/10. $1111 /$ j.1756-1051.2013.00116.x

Tomczyk M, Gudej J (2005) Polyphenolic compounds from Rubus saxatilis. Chem Nat Compd 41:349-351

Tozin LRDS, Mayo Marques MO, Maria Rodrigues T (2017) Herbivory by leaf-cutter ants changes the glandular trichomes density and the volatile components in an aromatic plant model. AoB Plants 9: plx057. https://doi.org/10.1093/aobpla/plx057

Upadhyaya MK, Furness NH (1998) Primocane morphology and leaf surface characteristics of greenhouse-grown red raspberry cultivars. Hortic Sci 33:330-332

Wang Z, Zeng X, Geng M, Chen C, Cai J, Yu X, Hou Y, Zhang H (2015) Health risks of heavy metals uptake by crops grown in a sewage irrigation area in China. Pol J Environ Stud 24:1379-1386. https:// doi.org/10.15244/pjoes/3528

Weryszko-Chmielewska E, Chwil M (2017) Structure of floral nectaries in Aesculus hippocastanum L. Acta Bot Croat 76:41-48. https://doi. org/10.1515/botcro-2016-0049

Wilkens T, Shea GO, Halbreich S, Stamp NE (1996) Resource availability and the trichome defenses of tomato plants. Oecologia 106:181-191

Wołonciej M, Milewska E, Roszkowska-Jakimiec W (2016) Trace elements as an activator of antioxidant enzymes. Postepy Hig Med Dosw 70:1483-1498. https://doi.org/10.5604/17322693.1229074

Zamani A, Attar F, Ghahreman A, Maroofi H (2008) Anatomical studies of genus Pyrus L. (Rosaceae) in Iran. Iran J Bot 14:132-143

Zhang TT, Lu CL, Jiang JG, Wang M, Wang DM, Zhu W (2015) Bioactivities and extraction optimization of crude polysaccharides from the fruits and leaves of Rubus chingii Hu. Carbohydr Polym 130:307-315. https://doi.org/10.1016/j.carbpol.2015.05.012

Publisher's note Springer Nature remains neutral with regard to jurisdictional claims in published maps and institutional affiliations. 